\title{
Identification of Aerosol Pollution Hotspots in Jiangsu Province of China
}

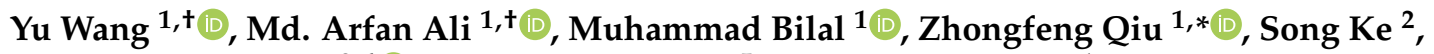 \\ Mansour Almazroui ${ }^{3,4}{ }^{\oplus}$, Md. Monirul Islam ${ }^{5}$ and Yuanzhi Zhang ${ }^{1}$
}

1 Lab of Environmental Remote Sensing (LERS), School of Marine Sciences (SMS), Nanjing University of Information Science and Technology (NUIST), Nanjing 210044, China; yuwang@nuist.edu.cn (Y.W.); md.arfanali@nuist.edu.cn (M.A.A.); muhammad.bilal@connect.polyu.hk (M.B.); yzhang209@nuist.edu.cn (Y.Z.)

2 Geological Survey of Jiangsu Province, Nanjing 210018, China; 20201209011@nuist.edu.cn

3 Center of Excellence for Climate Change Research, Department of Meteorology, King Abdulaziz University, Jeddah 21589, Saudi Arabia; mansour@kau.edu.sa

4 Climatic Research Unit, School of Environmental Sciences, University of East Anglia, Norwich NR4 7TJ, UK

5 Department of Electrical and Electronic Engineering, Begum Rokeya University, Rangpur 5404, Bangladesh; rajib.mmi@brur.ac.bd

* Correspondence: zhongfeng.qiu@nuist.edu.cn

+ These authors with equal contributions.

Citation: Wang, Y.; Ali, M..A.; Bilal, M.; Qiu, Z.; Ke, S.; Almazroui, M.; Islam, M..M.; Zhang, Y. Identification of Aerosol Pollution Hotspots in Jiangsu Province of China. Remote Sens. 2021, 13, 2842. https://doi.org/ $10.3390 / \mathrm{rs} 13142842$

Academic Editor: Maria João Costa

Received: 15 June 2021

Accepted: 14 July 2021

Published: 20 July 2021

Publisher's Note: MDPI stays neutral with regard to jurisdictional claims in published maps and institutional affiliations.

Copyright: (C) 2021 by the authors Licensee MDPI, Basel, Switzerland This article is an open access article distributed under the terms and conditions of the Creative Commons Attribution (CC BY) license (https:// creativecommons.org/licenses/by/ $4.0 /)$.

\begin{abstract}
Aerosol optical depth (AOD) is an important atmospheric parameter for climate change assessment, human health, and for total ecological situation studies both regionally and globally. This study used 21-year (2000-2020) high-resolution (1 km) Multiangle Implementation of Atmospheric Correction (MAIAC) algorithm-based AOD from the Moderate Resolution Imaging Spectroradiometer (MODIS) sensor onboard the Terra and Aqua satellites. MAIAC AOD was evaluated against Aerosol Robotic Network (AERONET) data across three sites (Xuzhou-CUMT, NUIST, and Taihu) located in Jiangsu Province. The study also investigated the spatiotemporal distributions and variations in AOD, with associated trends, and measured the impact of meteorology on AOD in the 13 cities of Jiangsu Province. The evaluation results demonstrated a high correlation $(r=0.867 \sim 0.929)$ between MAIAC AOD and AERONET data, with lower root mean squared error (RMSE $=0.130 \sim 0.287$ ) and mean absolute error (MAE $=0.091 \sim 0.198)$. In addition, the spatial distribution of AOD was higher $(>0.60)$ in most cities except the southeast of Nantong City (AOD $<0.4)$. Seasonally, higher AOD was seen in summer $(>0.70)$ than in spring, autumn, and winter, whereas monthly AOD peaked in June $(>0.9)$ and had a minimum in December $(<0.4)$ for all the cities. Frequencies of $0.3 \leq \mathrm{AOD}<0.4$ and $0.4 \leq \mathrm{AOD}<0.5$ were relatively common, indicating a turbid atmosphere, which may be associated with anthropogenic activities, increased emissions, and changes in meteorological circumstances. Trend analysis showed significant increases in AOD during 2000-2009 for all the cities, perhaps reflecting a booming economy and industrial development, with significant emissions of sulfur dioxide $\left(\mathrm{SO}_{2}\right)$, and primary aerosols. China's strict air pollution control policies and control of vehicular emissions helped to decrease AOD from 2010 to 2019, enhancing air quality throughout the study area. A notably similar pattern was observed for AOD and meteorological parameters (LST: land surface temperature, WV: water vapor, and P: precipitation), signifying that meteorology plays a role in terms of increasing and decreasing AOD.
\end{abstract}

Keywords: aerosol; AERONET; MODIS; MAIAC; AOD; trend

\section{Introduction}

Aerosols are mixtures of tiny solid and liquid particles suspended in the atmosphere, with a typical particle radius ranging from 0.001 to $100 \mu \mathrm{m}$ [1]. They are generated from many different sources across the world and released into the atmosphere as mineral dust, volcanic dust and ash, biomass ash, mist fog, smoke, sea salt, and particulate pollution 
from both natural and anthropogenic activities [2-6]. Aerosols severely impact human health, the climate, atmospheric visibility, air quality, and agricultural production [7-10]. They also play a significant role in the environment and climate, so that their long-term fluctuations and trends are crucial for climate change assessment [11-13]. According to the Fifth Assessment Report (AR5) of the Intergovernmental Panel on Climate Change [14], aerosols are the main source of uncertainty in climate change modeling and assessment. They directly lessen the amount of solar radiation that reaches the Earth's surface by absorbing and scattering the radiation, altering the balance of the Earth-atmosphere energy budget [15-17]. The IPCC [14] reported that absorption of radiant energy by aerosols leads to warming of the troposphere and cooling of the surface, potentially altering atmospheric visibility and the relative humidity, thereby affecting precipitation and cloud formation. In addition, aerosols indirectly affect climate change through aerosol-cloud interactions [18,19].

Aerosol optical properties are significant factors affecting atmospheric radiation and climate change; therefore, studies of long-term variations in these properties with the high spectral and temporal resolution are necessary. Such studies could explore important information for climate change prediction and estimation [14,20,21]. In this regard, extensive efforts have already been devoted to monitoring atmospheric aerosols with aerosol optical depth (AOD) globally. AOD is the key optical parameter used to estimate aerosol loading in the atmosphere [22]. Aerosols from natural and anthropogenic sources and transported by meteorological circumstances can sharply impact AOD distribution, which can form the basis for investigations of regional aerosol loading to show its effect on climate change and radiation $[23,24]$.

Ground-based networks such as the Aerosol Robotic Network (AERONET) and the China Aerosol Remote Sensing Network (CARSNET) have been widely used to obtain the long-term measurements of national, regional, and global aerosol optical properties around the world $[25,26]$. These networks provide an accurate and detailed description of atmospheric aerosols, offering insights into the temporal distributions of aerosol optical properties and their effect on the climate [27-30]. However, the limitations of the groundbased networks are the sparse station cover and scantiness of AOD spatial distributions [29].

Satellite remote sensing, for its part, allows long-term aerosol observation of national, regional, and global aerosol optical properties, overcoming the limitations of ground-based networks in providing regular near-real-time AOD measurements as well as the long-term aerosol variations at low-to-high spatial resolutions. Various satellite sensors such as the Total Ozone Monitoring Instrument (TOMS) [31], the Advanced Very High Resolution Radiometer (AVHRR) [32], MODIS (Moderate Resolution Imaging Spectroradiometer) [33-36], the Ozone Monitoring Instrument (OMI) [37], the Sea-Viewing Wide-Field of View Sensor (SeaWiFS) [38], GOES (Geostationary Operational Environmental Satellite) [39], GOCI (Geostationary Ocean Color Image) [40], and the Visible Infrared Imaging Radiometer (VIIRS) [41] provide long-term spatiotemporal aerosol data, which have been extensively used to investigate aerosol loading both regionally and globally. MODIS is the most popular and widely used and provides continuous long-term aerosol data allowing regular aerosol observation at national, regional, and global scales [33,42-44]. The MODIS instrument onboard the Terra and Aqua satellites provides AOD at $10 \mathrm{~km}$ spectral resolution over land using the Dark Target (DT) and Deep Blue (DB) and at $1 \mathrm{~km}$ using the Multiangle Implementation of atmospheric correction (MAIAC) algorithm. The DT algorithm was designed for vegetation and moist surfaces but has limitations over bright-reflecting surfaces [45], so Hsu et al. [46] proposed the DB algorithm to estimate AOD over bright-reflecting surfaces. To increase AOD retrieval accuracy and coverage with high-resolution $(1 \mathrm{~km})$ over different aerosol climatology and surface cover conditions, Lyapustin et al. [36,47,48] proposed the MAIAC algorithm, which is more accurate than DT and DB over vegetation, moist surfaces, and bright-reflecting surfaces. Even so, the effects of surface albedo, geography and elevation, and retrieval algorithms, mean that satellite datasets need continuous improvement to achieve higher accuracy [49-53]. 
Recently, aerosol products have been widely evaluated over land, including the American continents $[54,55]$ and South Asia [56], using the MODIS MAIAC algorithm. Although a few validation studies have also been conducted over China [57-59], the performance of the MAIAC algorithm is still unclear in China due to high levels of aerosol loading, and heterogeneity. Due to China's rapid social and economic development in recent years, the country is in line with serious aerosol pollution. According to China's Environmental Status Bulletin 2015, more than 70 prefecture-level cities of the BTH (Beijing-Tianjin-Hebei) region had 1710 severe and above pollution days and were given 154 heavy pollution weather warnings. Moreover, about 73 prefecture-level cities showed ambient air quality standards, and the rest of the cities (265) failed to reach the urban environmental air quality standards. According to the Environmental Performance Index Report (2016) announced by Yale University, the air quality of China ranked the second last in the world, only better than Bangladesh $[60,61]$. However, air quality problems are very noticeable in Jiangsu province, an economically developed province in eastern China covering a concentrated area of metropolises and large rural areas. This leads to the release of air pollutants from urban constructions, transportation, industrial production, and the burning of straw in agricultural production. This province is located in the climate transition zone between the northern and southern regions of China. It is a buffer zone between the BTH and the Yangtse River Delta, resulting in severe air pollution. Jiangsu's Environmental Status Bulletin (2012-2015) reported that 13 cities of Jiangsu Province did not meet the second level of national air quality standard; therefore, a study related to identifying aerosol pollution hotspots in the Jiangsu Province of China is important. To the best of our knowledge, no study has evaluated the MAIAC AOD against AERONET AOD at the local scale (e.g., Jiangsu Province), while analyzing long-term spatiotemporal distribution and variations in AOD and calculating its trend to find out the hotspots of aerosol pollution. Accordingly, evaluation of the MAIAC algorithm in Jiangsu Province is needed to investigate the spatiotemporal distribution and variations in AOD, shedding light on aerosols' effects on climate and pollution meteorology. The main objectives of this study are: (1) to evaluate the MAIAC AOD against AERONET AOD (NUIST, Taihu, and Xuzhou-CUMT); (2) to analyze the long-term spatiotemporal distribution of and variations in AOD, while calculating its trend; and (3) to study the relationship between AOD and meteorological parameters (LST, WV, and P) in the 13 cities of Jiangsu Province from 2000 to 2020. This study contributes to the literature by revealing city-level aerosol pollution distribution in Jiangsu Province based on the MODIS high-resolution MAIAC aerosol products, offering detailed data on the interactions between atmospheric pollutants for use in improving air quality at the city level.

\section{Materials and Methods}

\subsection{Study Area}

China, the largest Asian country, also has the largest population of any country in the world. It has 23 Provinces, 5 autonomous regions, 4 municipalities (Chongqing, Beijing, Shanghai, and Tianjin), and 2 administrative regions (Hong Kong and Macau). Jiangsu Province $\left(116^{\circ} 18^{\prime}-121^{\circ} 57^{\prime} \mathrm{E}, 30^{\circ} 45^{\prime}-35^{\circ} 20^{\prime} \mathrm{N}\right)$, which has historically been China's most politically, economically, and culturally developed region, covers about 102,600 square kilometers. Located in the east of China and encompassing much of the Yangtse River Delta (YRD), with its many rivers and lakes, Jiangsu is the most densely populated and agriculturally fertile region of China. About $70 \%$ of its populace of 80 million live in urban areas. After the economic reforms in 1990, it became a hotspot for economic development and now has the highest per-capita GDP of China's 23 Provinces. Jiangsu is the home of many of the world's leading exporters of chemical, textiles, and electronic equipment, which are located in its 13 major cities (Figure 1). 


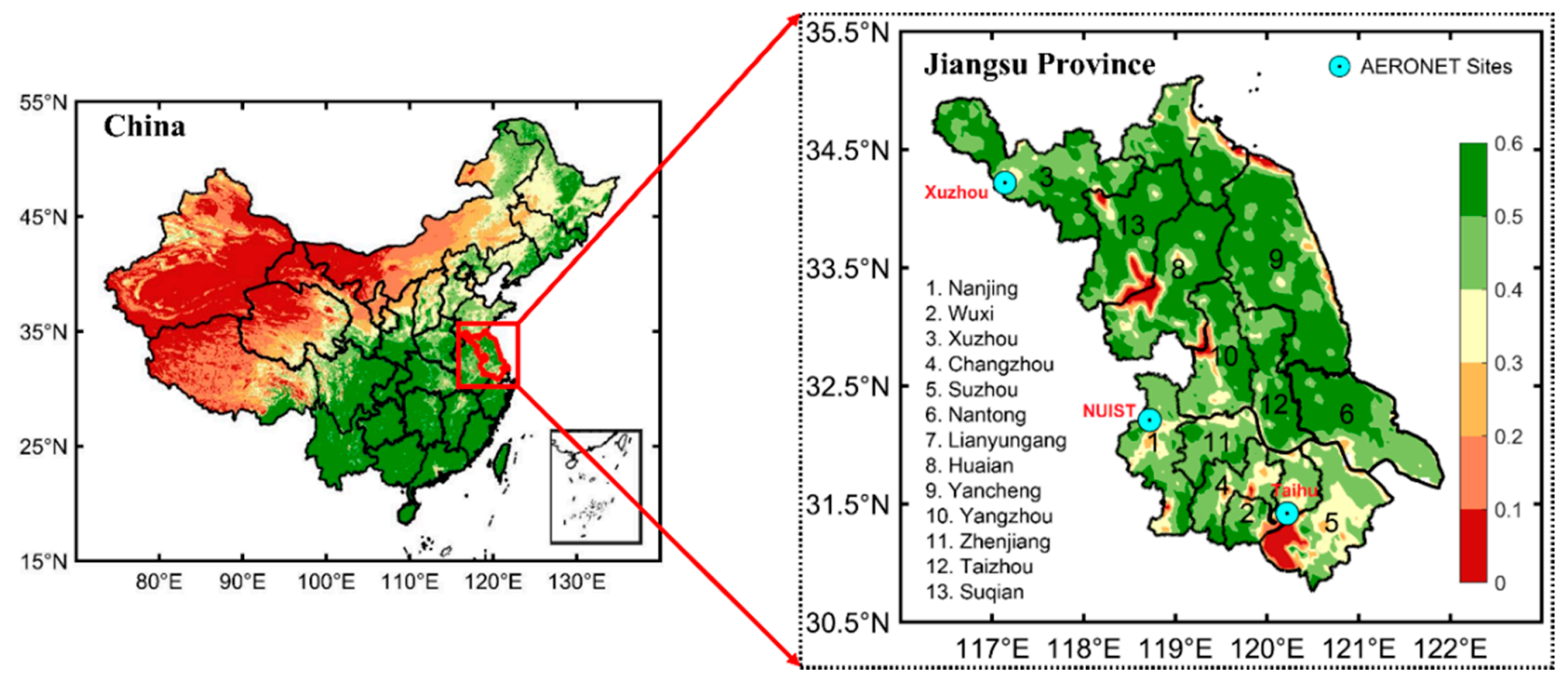

Figure 1. Map of Jiangsu Province with major cities, China. The background image reveals the multiyear (2000-2020) averages of MODIS NDVI, with arid surfaces (NDVI < 0.2), lighter or sparse vegetation $(0.2<\mathrm{NDVI}<0.4)$, moderate vegetation $(0.4<\mathrm{NDVI}<0.5)$, and dark vegetation $(\mathrm{NDVI}>0.5)$.

Most parts of Jiangsu Province have a humid subtropical climate that begins to transition into a humid continental climate in the far north. The annual mean temperature varies from $13{ }^{\circ} \mathrm{C}$ to $16^{\circ} \mathrm{C}$, and precipitation from $782 \mathrm{~mm}$ to $1150 \mathrm{~mm}$. There are four distinct seasons: winter (December, January, February); spring (March, April, May); summer (June, July, August); and autumn (September, October, November). In January, the average temperature ranges from $-1{ }^{\circ} \mathrm{C}$ to $4{ }^{\circ} \mathrm{C}$, while in June this range is from $26{ }^{\circ} \mathrm{C}$ to $29^{\circ} \mathrm{C}$. Besides, the most frequent rainfall happens in spring and summer, while rainstorms with typhoons occur in the late summer and autumn.

\subsection{MAIAC AOD}

The MAIAC algorithm assumes that the surface reflectance evolves smoothly over time and displays high variability over space, while the aerosol changes smoothly (low variability) over space [46]. To retrieve aerosol and surface parameters: Firstly, the algorithm resamples MODIS L1B radiances into a $1 \mathrm{~km}$ fixed grid. Then, the gridded data are split into $1200 \mathrm{~km}$ titles and placed in a queue containing from 5 (over the pole) to 16 (over the equator) days. This gives a time dimension for each $1 \mathrm{~km}$ grid cell. The cloud mask combined with discriminating absorbing aerosols (dust or smoke) enables MAIAC to distinguish most aerosol emission sources at $1 \mathrm{~km}$ resolution, including high intensity plumes, without masking them as clouds [46]. The MAIAC aerosol retrieval algorithm uses minimum reflectance technique to characterize surface reflectance with spectral surface reflectance ratios $(\mathrm{SRC})$ such as $0.47 / 2.13(\mu \mathrm{m})$ and $0.47 / 0.55(\mu \mathrm{m})$ [46]. Notably, this code runs dynamically and continuously updates the SRC. The angular dependence of SRC is estimated based on three angular bins. Finally, the AOD retrieval algorithm uses different band combinations such as $0.47,0.55,0.65$, and $2.13 \mu \mathrm{m}$, depending on the surface brightness and defined regional aerosol models for the MAIAC look-up table (see Lyapustin et al. [46]). The MAIAC AOD product is a long-term dataset that offers a good spatio-temporal resolution to monitor aerosols from local to global scale and this dataset has been widely used by researchers [49,52,54,57]. The algorithm also provides cloud masks and water vapor at NIR bands. In this paper, we used the MAIAC AOD (550 nm) over Jiangsu Province to study spatio-temporal variations of AOD and its evaluation against ground measurements from 2000 to 2020 [49]. The data were downloaded from the NASA website (link: https:// search.earthdata.nasa.gov/search?q=MCD19A2; accessed on 1 March 2021). 


\subsection{AERONET AOD}

The Aerosol Robotic Network (AERONET) provides AOD that is calculated from direct solar radiation measurements under cloud-free conditions at different wavelengths, with high temporal resolution ( $15 \mathrm{~min})$ and low uncertainty $(\sim 0.01-0.02)$ [25]. The AERONET data holds three levels, namely Level 1 for unscreened, Level 1.5 for cloud-screened, and Level 2.0 for quality-assured. This data network has been verified as the standard source due to its high quality and accuracy, global range, free cost, and easy access. Data (e.g., AOD and water vapor) from AERONET are widely used for evaluation and bias corrections of satellite-based water vapor and aerosol products [35,62-64]. There are three AERONET sites, namely NUIST, Taihu, and Xuzhou, located in Jiangsu Province (Figure 1 and Table 1). Due to less available data at $550 \mathrm{~nm}$, the present study used both Level 1.5 and 2 AOD at $440 \mathrm{~nm}$ to estimate AOD at $550 \mathrm{~nm}$ based on the Ångström empirical methods (Equation (1)):

$$
\mathrm{AOD}_{550}=\mathrm{AOD}_{440} \times\left(\frac{550}{440}\right)^{-\mathrm{AE}_{440-670}} .
$$

Table 1. AERONET sites information and data availability.

\begin{tabular}{ccccc}
\hline Sites & Latitude (N) & Longitude (E) & Altitude (m) & Period \\
\hline NUIST & $32.20648^{\circ}$ & $118.71715^{\circ}$ & 62 & $2007-2010$ \\
Taihu & $31.42100^{\circ}$ & $120.21533^{\circ}$ & 20 & $2001-2018$ \\
Xuzhou-CUMT & $34.21667^{\circ}$ & $117.14167^{\circ}$ & 59.7 & $2013-2019$ \\
\hline
\end{tabular}

Here, $\mathrm{AE}_{440-670(\mathrm{~nm})}$ is the Ångström Exponent and $\mathrm{AOD}_{550(\mathrm{~nm})}$ indicates the aerosol optical depth at $550 \mathrm{~nm}$. The data were downloaded from the NASA AERONET site (link: https:/ /aeronet.gsfc.nasa.gov/; accessed on 10 March 2021).

\subsection{Meteorological Data}

To investigate the relationship between meteorological parameters and satellite-based MAIAC AOD, this study used meteorological parameters such as land surface temperature (LST: MOD11C3v006 and MYD11C3v006) and Wwter vapor (WV: MOD08_M3v6.1 and MYD08_M3v6.1) from the MODIS sensor, and precipitation from Global Precipitation Measurement (GPM: GPM_3IMERGM_06). The 20 years (2000-2020) data were downloaded from the link: https:/ / giovanni.gsfc.nasa.gov/; accessed on 15 March 2021.

\subsection{Research Methodology}

In this study, several statistical methods were used to evaluate the MAIAC AOD against AEROENT AOD. Details include the following:

- $\quad$ The study extracted point data from MAIAC AOD using the spatial widow of $3 \times 3$ pixels surrounding the AERONET sites, which were averaged if at least 2 pixels out of the 9 pixels were available. The AERONET AOD was averaged within a \pm 60 minute time window from the satellite local time (Terra: 10:30 am, Aqua: 01:30 pm).

- A reduced major axis (RMA) method was used to calculate slope and intercept between the satellite-based MAIAC and AERONET AODs [65]. The slope defines the inaccuracy related to using an imperfect aerosol model, while the intercept implies the inaccuracy related to incorrect surface reflectance calculation $[3,66]$. In RMA, the following Equations (2) and (3) are used to calculate the slope ( $\beta$ ) and intercept $(\alpha)$ :

$$
\begin{gathered}
\beta=\frac{\sigma_{y}}{\sigma_{x}} . \\
\alpha=\bar{Y}-\left(\frac{\sigma_{y}}{\sigma_{x}}\right) \bar{X}
\end{gathered}
$$


where $\bar{X}$ and $\bar{Y}$ are defined as the means of $X$ and $Y$, and $\sigma_{x}$ and $\sigma_{y}$ indicate the standard deviation of $X$ and $Y$, respectively. A perfect estimation of satellite-based MAIAC AOD is indicated by values of $\beta(=1)$ and $\alpha(=0)$.

- To determine the uncertainty and accuracy of the satellite-based MAIAC AOD products, this study used the following Equations (4)-(8) for Pearson's correlation (r), root mean squared error (RMSE), mean absolute error (MAE), relative mean bias (RMB), and expected error envelope (EE) $[5,27,67]$.

$$
\begin{gathered}
r=\frac{\sum_{\mathrm{i}=1}^{\mathrm{n}}\left(\mathrm{x}_{\mathrm{i}}-\overline{\mathrm{x}}\right)\left(\mathrm{y}_{\mathrm{i}}-\overline{\mathrm{y}}\right)}{\sqrt{\sum_{\mathrm{i}=1}^{\mathrm{n}}\left(\mathrm{x}_{\mathrm{i}}-\overline{\mathrm{x}}\right)^{2}} \sum_{\mathrm{i}=1}^{\mathrm{n}}\left(\mathrm{y}_{\mathrm{i}}-\overline{\mathrm{y}}\right)^{2}} . \\
\mathrm{RMSE}=\sqrt{\frac{1}{\mathrm{n}} \sum_{\mathrm{i}=1}^{\mathrm{n}}\left(\mathrm{AOD}_{\text {Satellite }}-\mathrm{AOD}_{\mathrm{AERONET}}\right)^{2}} . \\
\mathrm{MAE}=\frac{1}{\mathrm{n}} \sum_{\mathrm{i}=1}^{\mathrm{n}}\left|\left(\mathrm{AOD}_{\text {Satellite }}-\mathrm{AOD}_{\text {AERONET }}\right)\right| . \\
\mathrm{RMB}=\left|\frac{\overline{\mathrm{AOD}}_{\text {Satellite }}}{\overline{\mathrm{AOD}}_{\text {AERONET }}}\right| . \\
\mathrm{EE}= \pm\left(0.05+0.15 \times \mathrm{AOD}_{\text {AERONET }}\right) .
\end{gathered}
$$

Here, $\mathrm{RMB}=1$ defines the normal estimation of MAIAC AOD, while RMB $<1$ and $>1$ indicates underestimation and overestimation, respectively.

- The Mann-Kendal test was used to calculate the significance of any AOD trends (increasing or decreasing), while Sen's slope method was used to calculate the magnitude of AOD trends. The methods used in this study are discussed below.

If $x_{1}, x_{2}, x_{3} \ldots \ldots x_{i}$ represent $n$ data points where $x_{j}$ represents the data point at time $j$, then the Mann-Kendall statistic, Sen's slope (S) is given by Mann and Kendall $[68,69]$

$$
\mathrm{S}=\sum_{\mathrm{k}=1}^{\mathrm{n}-1} \sum_{\mathrm{j}=\mathrm{k}+1}^{\mathrm{n}} \operatorname{sign}\left(\mathrm{x}_{\mathrm{j}}-\mathrm{x}_{\mathrm{k}}\right) .
$$

where

$$
\operatorname{sign}\left(x_{j}-x_{k}\right)=\left\{\begin{array}{rl}
1, & \text { if }\left(x_{j}-x_{k}\right)>0 \\
0, & \text { if }\left(x_{j}-x_{k}\right)=0 \\
-1, & \text { if }\left(x_{j}-x_{k}\right)<0
\end{array} .\right.
$$

$\mathrm{S}$ is associated with normally distributed probability and the sample size, $\mathrm{n}$, were calculated to statistically quantify the significance of AOD trends. Normalized statistics $(\mathrm{Z})$ were calculated using the following equation:

$$
\mathrm{Z}=\left\{\begin{aligned}
\frac{\mathrm{S}-1}{\sqrt{\operatorname{VAR}(\mathrm{S})},} & \text { if } S>0 \\
0, & \text { if } S=0 \\
\frac{\mathrm{S}-1}{\sqrt{\operatorname{VAR}(\mathrm{S})},} & \text { if } S<0
\end{aligned}\right.
$$

At the 95\% significance level, the null hypothesis of no trend is rejected if $|Z|>1.96$.

Sen's slope technique [70] was used to calculate the slope as a change in measurement per unit change in time

$$
\mathrm{Q}^{\prime}=\frac{\mathrm{x}_{\mathrm{t}^{\prime}}-\mathrm{x}_{\mathrm{t}}}{\mathrm{t}^{\prime}-\mathrm{t}} .
$$

where, $\mathrm{Q}^{\prime}=$ slope between data points $\mathrm{x}_{\mathrm{t}^{\prime}}$ and $\mathrm{x}_{\mathrm{t}}$

$\mathrm{x}_{\mathrm{t}^{\prime}}=$ data measurement at a time $\mathrm{t}^{\prime}$

$x_{t}=$ data measurement at time $t$

Sen's estimator of the slope is attained by the median slope 


$$
\begin{gathered}
\mathrm{Q}=\mathrm{Q}^{\prime}[\mathrm{N}+1 / 2] \text { if } \mathrm{N} \text { is odd } \\
=\left(\mathrm{Q}_{[\mathrm{N} / 2]}^{\prime}+\mathrm{Q}_{[(\mathrm{N}+2) / 2]}^{\prime}\right) / 2 \text { if } \mathrm{N} \text { is even }
\end{gathered}
$$

where $\mathrm{N}$ is the number of calculated slopes.

\section{Results and Discussion}

\subsection{Evaluations of MAIAC AOD against AERONET AOD}

Figure 2 and Table S1 show the evaluation of MODIS mean (Terra and Aqua) MAIAC AOD against ground-based AERONET data for three sites in Jiangsu Province during 2000-2020. The MODIS MAIAC and AERONET AOD showed good consistency in that at the Xuzhou-CUMT site, they have a higher correlation $(r=0.929)$, more retrievals falling within the EE envelope $(75.84 \%)$, and lower errors $(\mathrm{RMSE}=0.130, \mathrm{MAE}=0.091)$ than at the NUIST $(0.867,62.03 \%, 0.287,0.179)$ or Taihu $(0.914,40.22 \%, 0.253,0.198)$ sites (Figure 2 and Table S1). Moreover, the RMB value (1.063) at the Xuzhou-CUMT site is closer to unity compared to the NUIST (0.838) and Taihu (1.249) sites. This suggests that AOD errors estimated by the MAIAC algorithm were smaller at the Xuzhou-CUMT site ( $6.3 \%$ overestimation) than at the Taihu site ( $24.9 \%$ overestimation), or the NUIST site $(16.2 \%$ underestimation). Under- and overestimation of AOD occur when using imperfect aerosol models and surface reflectance parameterizations in the look-up table, as indicated by the slope and intercept values [3,5,66,67,71]. Seasonally, the MAIAC algorithm, as with an annual one, produced more consistent results at the Xuzhou-CUMT site than at the NUIST and Taihu sites (Figure 2 and Table S1). Overall, the MAIAC algorithm showed a good agreement with AERONET data, making these data valuable for the study of long-term spatiotemporal distributions of and variations in AOD along with associated trends, revealing aerosol pollution distribution at a finer scale globally. However, in this study, we used the mean (Terra and Aqua) MODIS-MAIAC AOD product for its higher spatial and temporal coverage in Jiangsu Province.

\subsection{Spatial Distributions of MAIAC AOD}

Figure 3 represents the annual and seasonal spatial distribution of AOD obtained from the mean (Terra and Aqua) MAIAC algorithm in Jiangsu Province from 2000 to 2020. It is important to mention that due to the limitations of the MAIAC algorithm over the body of water, we have masked the body of water from the AOD map, resulting in that place appearing to be white (Figure 3). The spatial distribution of annual mean AOD was high ( $>0.60)$ in most cities of Jiangsu Province except for the southeast of Nantong city $(<0.4)$ (Figure 3). For the 13 studied cities, the 21-year city-level annual mean AOD was highest in Xuzhou ( $0.73 \pm 0.10)$, followed by Lianyungang $(0.70 \pm 0.10)$, Suqian and Taizhou (0.66 \pm 0.09$)$, Yangzhou (0.65 \pm 0.09$)$, Huaian $(0.65 \pm 0.08)$, Nanjing $(0.63 \pm 0.09)$, Changzhou (0.62 \pm 0.09$)$, Zhenjiang $(0.61 \pm 0.10)$, Suzhou and Wuxi $(0.61 \pm 0.09)$, Yancheng $(0.61 \pm 0.08)$, and Nantong $(0.59 \pm 0.08)$ (Figure 4 and Table 2$)$. The AOD values for the 13 cities were notably close to one another, indicating the presence of substantial aerosol emissions in Jiangsu Province $(0.66 \pm 0.08)$, which are strongly influenced by anthropogenic activities, resulting in high AOD. Che et al. [23] reported that urban areas are strongly impacted by anthropogenic activities, leading to high AOD in northeast China. Similar results were documented by [72]. High AOD may also result because the geographical position of the Yellow Sea is favorable for the formation of sea-land breezes and the associated mesoscale atmospheric circulation, which together influence the aerosol transport, producing high AOD in the 13 cities of Jiangsu Province. 

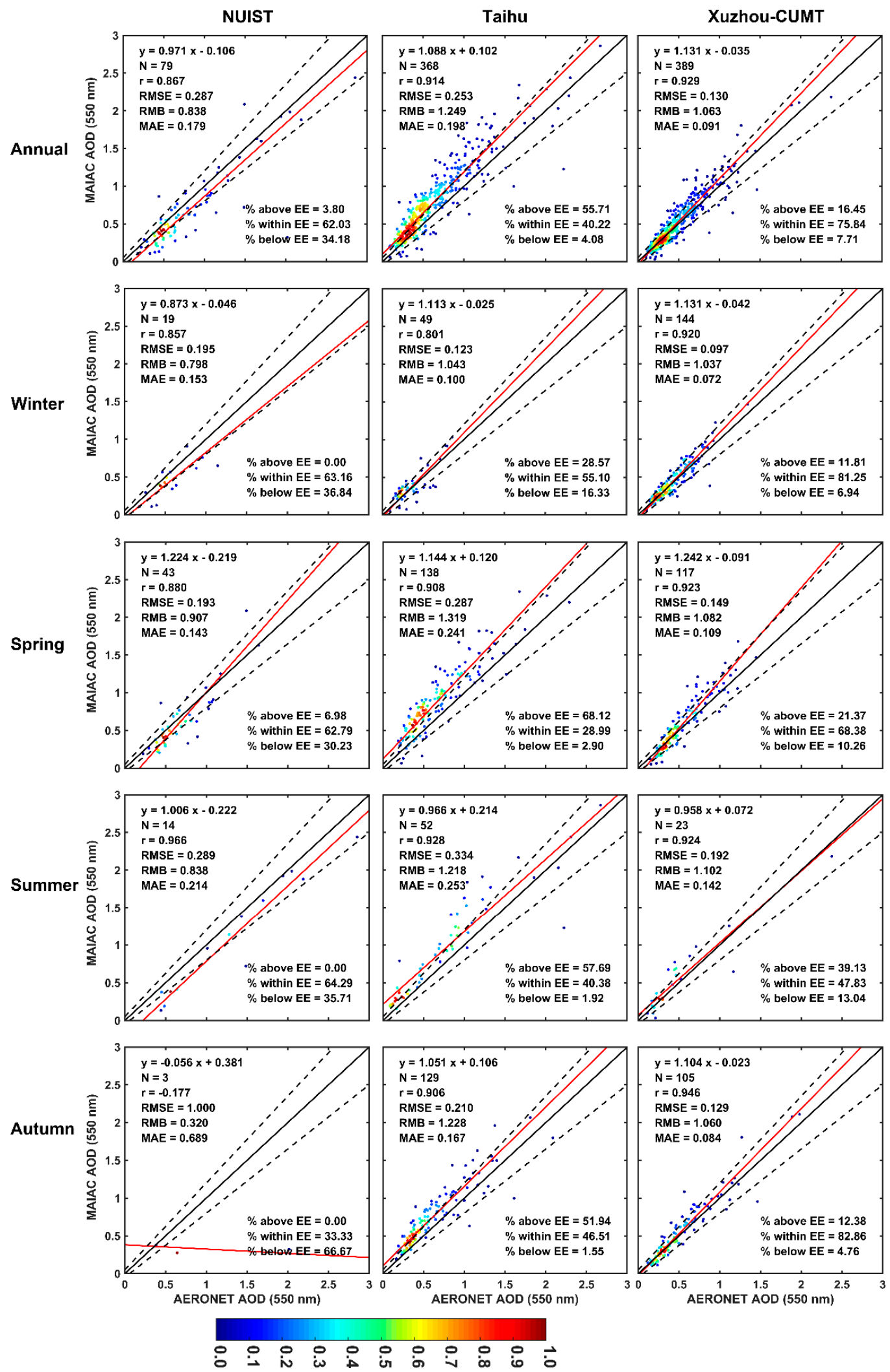

$\dot{0} \dot{0}$ i

Figure 2. Evaluation of high-resolution (1 km) MODIS MAIAC AOD against AERONET AOD over NUIST, Taihu, and Xuzhou-CUMT sites located in Jiangsu Province from 2000-2020. The normalized data density is shown in color. The black solid line $=1: 1$, black dashed lines $=$ EE lines, and red solid line $=$ regression line. 

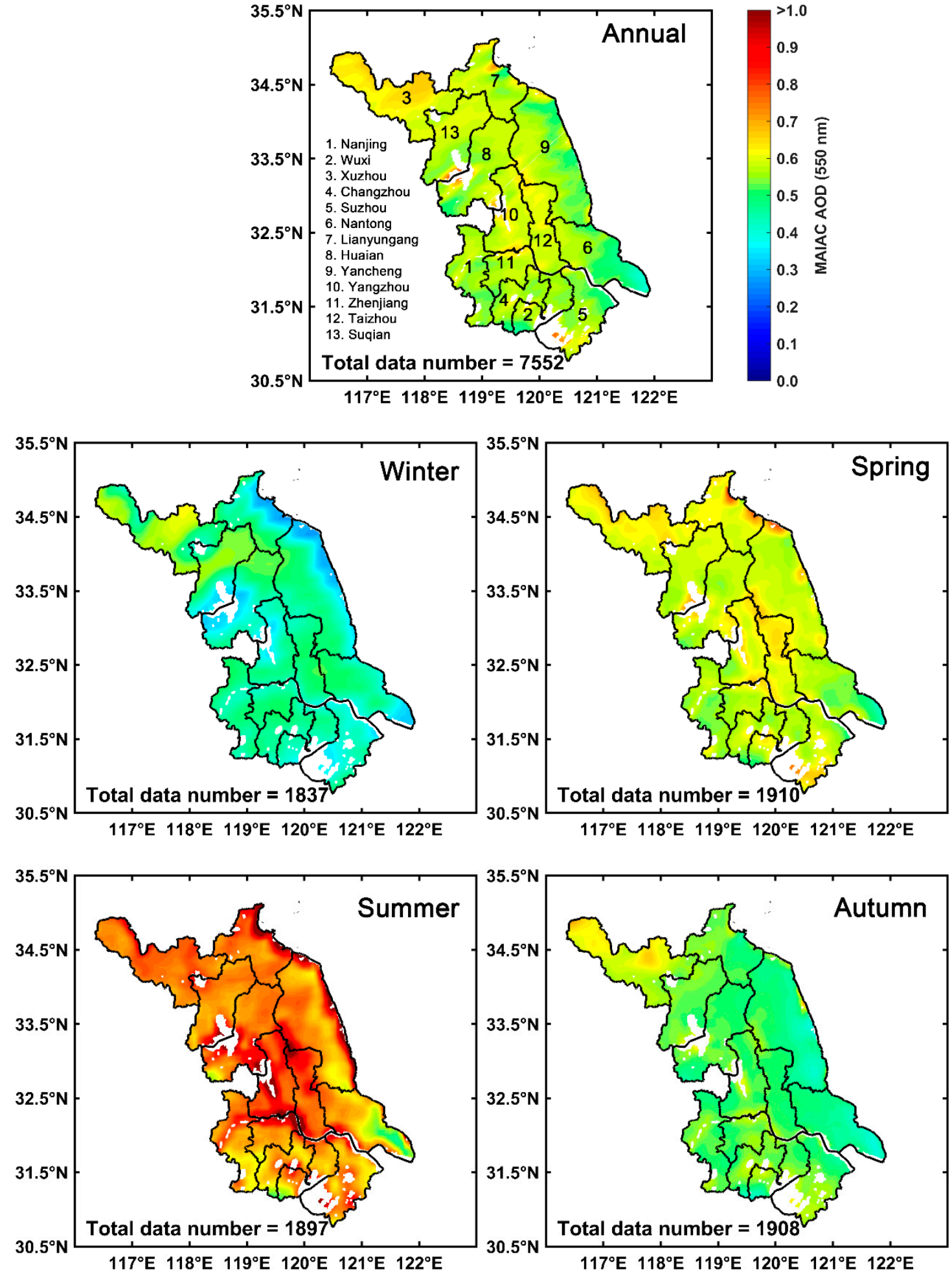

Figure 3. Annual and seasonal spatial distribution of high-resolution MODIS MAIAC AOD over Jiangsu Province from 2000 to 2020. 

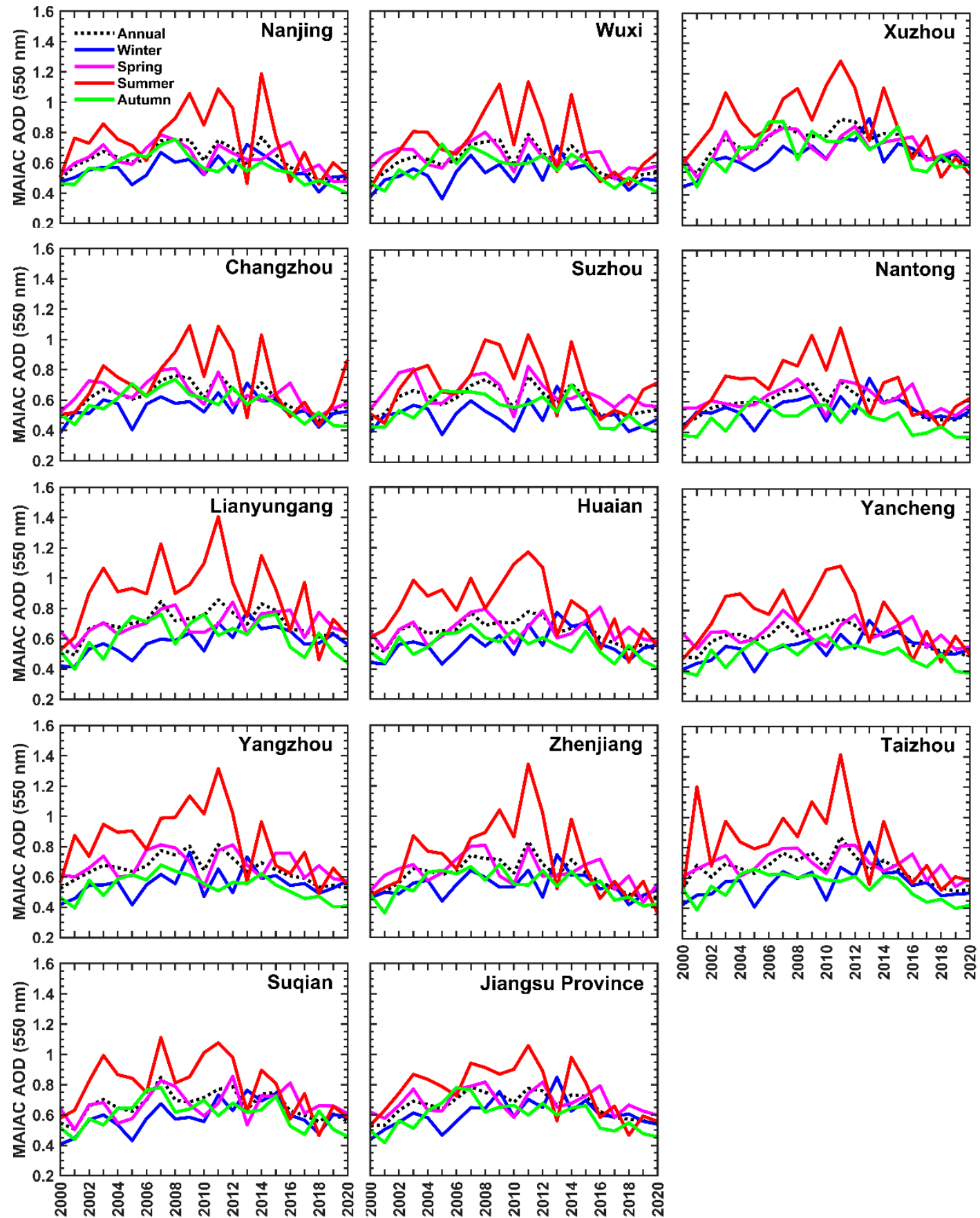

Figure 4. Annual and seasonal variations of high-resolution MODIS MAIAC AOD in 13 cities in Jiangsu Province from 2000 to 2020 . 


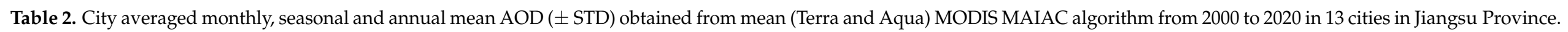

\begin{tabular}{|c|c|c|c|c|c|c|c|c|c|c|c|c|c|c|}
\hline Time & Nanjing & Wuxi & Xuzhou & Changzhou & Suzhou & Nantong & Lianyungang & Huaian & Yancheng & Yangzhou & Zhenjiang & Taizhou & Suqian & $\begin{array}{l}\text { Jiangsu } \\
\text { Province }\end{array}$ \\
\hline Jan & $0.55 \pm 0.11$ & $0.52 \pm 0.09$ & $0.68 \pm 0.12$ & $0.53 \pm 0.09$ & $0.50 \pm 0.09$ & $0.57 \pm 0.12$ & $0.59 \pm 0.14$ & $0.57 \pm 0.12$ & $0.56 \pm 0.09$ & $0.55 \pm 0.09$ & $0.54 \pm 0.10$ & $0.57 \pm 0.10$ & $0.60 \pm 0.13$ & $0.63 \pm 0.10$ \\
\hline $\mathrm{Feb}$ & $0.62 \pm 0.14$ & $0.56 \pm 0.17$ & $0.71 \pm 0.18$ & $0.59 \pm 0.16$ & $0.53 \pm 0.14$ & $0.59 \pm 0.16$ & $0.67 \pm 0.15$ & $0.62 \pm 0.16$ & $0.60 \pm 0.13$ & $0.62 \pm 0.21$ & $0.59 \pm 0.15$ & $0.61 \pm 0.17$ & $0.63 \pm 0.16$ & $0.67 \pm 0.17$ \\
\hline Mar & $0.65 \pm 0.14$ & $0.62 \pm 0.11$ & $0.74 \pm 0.10$ & $0.63 \pm 0.12$ & $0.63 \pm 0.12$ & $0.64 \pm 0.13$ & $0.70 \pm 0.12$ & $0.67 \pm 0.12$ & $0.66 \pm 0.12$ & $0.67 \pm 0.13$ & $0.63 \pm 0.11$ & $0.68 \pm 0.11$ & $0.69 \pm 0.16$ & $0.70 \pm 0.11$ \\
\hline Apr & $0.62 \pm 0.10$ & $0.63 \pm 0.12$ & $0.71 \pm 0.13$ & $0.64 \pm 0.13$ & $0.66 \pm 0.11$ & $0.63 \pm 0.09$ & $0.72 \pm 0.13$ & $0.65 \pm 0.09$ & $0.65 \pm 0.09$ & $0.68 \pm 0.10$ & $0.63 \pm 0.12$ & $0.69 \pm 0.09$ & $0.67 \pm 0.12$ & $0.69 \pm 0.10$ \\
\hline May & $0.63 \pm 0.14$ & $0.66 \pm 0.12$ & $0.68 \pm 0.16$ & $0.65 \pm 0.13$ & $0.69 \pm 0.18$ & $0.59 \pm 0.11$ & $0.67 \pm 0.12$ & $0.66 \pm 0.13$ & $0.64 \pm 0.10$ & $0.69 \pm 0.15$ & $0.64 \pm 0.15$ & $0.70 \pm 0.12$ & $0.65 \pm 0.13$ & $0.67 \pm 0.10$ \\
\hline Jun & $0.97 \pm 0.32$ & $0.88 \pm 0.30$ & $0.99 \pm 0.29$ & $0.89 \pm 0.34$ & $0.87 \pm 0.27$ & $0.86 \pm 0.29$ & $1.00 \pm 0.28$ & $0.99 \pm 0.31$ & $0.85 \pm 0.27$ & $1.07 \pm 0.35$ & $0.89 \pm 0.36$ & $1.07 \pm 0.48$ & $0.92 \pm 0.25$ & $0.92 \pm 0.23$ \\
\hline Jul & $0.64 \pm 0.25$ & $0.67 \pm 0.25$ & $0.87 \pm 0.23$ & $0.67 \pm 0.31$ & $0.68 \pm 0.25$ & $0.70 \pm 0.26$ & $0.96 \pm 0.28$ & $0.83 \pm 0.27$ & $0.83 \pm 0.28$ & $0.79 \pm 0.27$ & $0.64 \pm 0.29$ & $0.81 \pm 0.28$ & $0.83 \pm 0.28$ & $0.75 \pm 0.20$ \\
\hline Aug & $0.64 \pm 0.22$ & $0.62 \pm 0.21$ & $0.72 \pm 0.20$ & $0.61 \pm 0.20$ & $0.63 \pm 0.21$ & $0.52 \pm 0.17$ & $0.71 \pm 0.25$ & $0.60 \pm 0.19$ & $0.57 \pm 0.18$ & $0.63 \pm 0.21$ & $0.64 \pm 0.25$ & $0.60 \pm 0.20$ & $0.63 \pm 0.16$ & $0.60 \pm 0.16$ \\
\hline Sep & $0.57 \pm 0.16$ & $0.57 \pm 0.14$ & $0.65 \pm 0.16$ & $0.60 \pm 0.17$ & $0.57 \pm 0.16$ & $0.42 \pm 0.11$ & $0.59 \pm 0.19$ & $0.52 \pm 0.14$ & $0.45 \pm 0.11$ & $0.50 \pm 0.13$ & $0.52 \pm 0.17$ & $0.50 \pm 0.12$ & $0.58 \pm 0.16$ & $0.58 \pm 0.12$ \\
\hline Oct & $0.57 \pm 0.13$ & $0.55 \pm 0.12$ & $0.76 \pm 0.22$ & $0.56 \pm 0.12$ & $0.53 \pm 0.12$ & $0.46 \pm 0.12$ & $0.62 \pm 0.17$ & $0.57 \pm 0.15$ & $0.50 \pm 0.12$ & $0.53 \pm 0.12$ & $0.56 \pm 0.10$ & $0.55 \pm 0.11$ & $0.62 \pm 0.18$ & $0.59 \pm 0.15$ \\
\hline Nov & $0.55 \pm 0.09$ & $0.55 \pm 0.11$ & $0.66 \pm 0.12$ & $0.56 \pm 0.09$ & $0.55 \pm 0.10$ & $0.56 \pm 0.12$ & $0.63 \pm 0.12$ & $0.58 \pm 0.09$ & $0.57 \pm 0.10$ & $0.57 \pm 0.08$ & $0.55 \pm 0.10$ & $0.59 \pm 0.10$ & $0.62 \pm 0.09$ & $0.61 \pm 0.08$ \\
\hline Winter & $0.56 \pm 0.08$ & $0.52 \pm 0.09$ & $0.66 \pm 0.10$ & $0.54 \pm 0.08$ & $0.51 \pm 0.08$ & $0.55 \pm 0.08$ & $0.58 \pm 0.09$ & $0.56 \pm 0.09$ & $0.55 \pm 0.08$ & $0.56 \pm 0.09$ & $0.54 \pm 0.08$ & $0.56 \pm 0.10$ & $0.59 \pm 0.10$ & $0.61 \pm 0.09$ \\
\hline Spring & $0.63 \pm 0.09$ & $0.64 \pm 0.08$ & $0.71 \pm 0.09$ & $0.64 \pm 0.09$ & $0.66 \pm 0.10$ & $0.62 \pm 0.08$ & $0.70 \pm 0.08$ & $0.66 \pm 0.08$ & $0.65 \pm 0.08$ & $0.68 \pm 0.09$ & $0.63 \pm 0.10$ & $0.69 \pm 0.08$ & $0.67 \pm 0.10$ & $0.69 \pm 0.08$ \\
\hline Summer & $0.75 \pm 0.21$ & $0.72 \pm 0.21$ & $0.86 \pm 0.22$ & $0.73 \pm 0.20$ & $0.72 \pm 0.18$ & $0.70 \pm 0.18$ & $0.89 \pm 0.24$ & $0.80 \pm 0.20$ & $0.75 \pm 0.19$ & $0.83 \pm 0.22$ & $0.72 \pm 0.25$ & $0.82 \pm 0.24$ & $0.79 \pm 0.18$ & $0.76 \pm 0.17$ \\
\hline Autumn & $0.56 \pm 0.09$ & $0.56 \pm 0.09$ & $0.69 \pm 0.12$ & $0.57 \pm 0.09$ & $0.55 \pm 0.10$ & $0.48 \pm 0.08$ & $0.61 \pm 0.12$ & $0.56 \pm 0.08$ & $0.51 \pm 0.08$ & $0.53 \pm 0.08$ & $0.55 \pm 0.09$ & $0.54 \pm 0.08$ & $0.60 \pm 0.10$ & $0.59 \pm 0.10$ \\
\hline Annual & $0.63 \pm 0.09$ & $0.61 \pm 0.09$ & $0.73 \pm 0.10$ & $0.62 \pm 0.09$ & $0.61 \pm 0.09$ & $0.59 \pm 0.08$ & $0.70 \pm 0.10$ & $0.65 \pm 0.08$ & $0.61 \pm 0.08$ & $0.65 \pm 0.09$ & $0.61 \pm 0.10$ & $0.66 \pm 0.09$ & $0.66 \pm 0.09$ & $0.66 \pm 0.08$ \\
\hline
\end{tabular}


Seasonally, spatial AOD was highest in summer followed by spring, autumn, and winter (Figure 3), in line with the findings of two earlier studies over China as a whole and the Sichuan Basin in particular [73,74]. In summer, spatially high AOD (>0.7) was found throughout Jiangsu Province except in the southeast of Nantong City (0.45). Most photochemical reactions occur at higher temperatures, when plenty of water vapor and droplets are suspended in the atmosphere, likely creating high AOD over the study area [75,76]. Furthermore, influence from the East Asian summer monsoon produces higher relative humidity during the summer season, resulting in high AOD $[77,78]$. The higher summer AOD may also be associated with increased emissions of anthropogenic aerosol from agricultural waste and biomass burning [71]. The second peak in AOD (0.50 0.70) was observed during spring in most of Jiangsu's cities, perhaps as a result of frequent sand and dust storms originating from the Taklamakan Desert, abundant biomass-burning activities, and lower levels of vegetation $[74,79,80]$. High spring winds could also substantially pick up and carry soil, dust, and biological particulate matter into the atmosphere, resulting in high AOD $[81,82]$. Notably, all the 13 studied cities had higher AOD in summer than in spring, autumn, and winter (Figure 4 and Table 2). Specifically, in summer, the 21-year city-level seasonal mean AOD was highest in Lianyungang $(0.89 \pm 0.24)$ and lowest in Nantong $(0.70 \pm 0.18)$, whereas spring city-level mean AOD was highest in Xuzhou $(0.71 \pm 0.09)$ and lowest in Nantong $(0.62 \pm 0.08)$ (Figure 4 and Table 2). Autumn mean AOD was highest in Xuzhou $(0.69 \pm 0.12)$ and lowest in Nantong $(0.48 \pm 0.08)$, whereas winter AOD peaked in Xuzhou $(0.66 \pm 0.10)$ and reached its lowest in Suzhou $(0.51 \pm 0.08)$. Interestingly, Jiangsu Province had a higher AOD in winter $(0.61 \pm 0.09)$ than in autumn $(0.59 \pm 0.10)$ (Figure 4 and Table 2).

Over the long-term, the monthly and spatial mean AOD rose gradually from January and peaked in June (>0.9), then generally declined with some fluctuations until December (low: $<0.4$ ) throughout Jiangsu Province (Figure 5). This fluctuation was attributed to variations in aerosol load and particle size originating from various source regions $[82,83]$. High AOD is associated with heavy emissions caused by the burning of summer agricultural waste [71,84]. The city-level monthly mean AOD also peaked in June and was lowest in December for the 13 cities of Jiangsu Province (Figure S1 and Table 2).

\subsection{Frequency Distribution of $A O D$}

Figure 6 shows the annual and seasonal frequency distribution of AOD based on daily datasets for the 13 cities of Jiangsu Province from 2000 to 2020. During the study period, at an annual scale, AOD occurrence frequency was least for the $0.0 \leq \mathrm{AOD}<0.1 \mathrm{bin}$, being $<1.79 \%$ for the 13 cities of Jiangsu Province, indicating extremely clean conditions (Figure 6). Specifically, the occurrence frequency of $0.0 \leq \mathrm{AOD}<0.1$ was comparatively high in Nantong $(1.79 \%)$, Zhenjiang $(1.12 \%)$, and Yancheng $(1.05 \%)$, but the other cities in Jiangsu Province had AOD frequencies of less than $0.80 \%$. Moreover, compared with the $0.0 \leq \mathrm{AOD}<0.1 \mathrm{bin}$, AOD occurrence frequencies substantially increased, peaking in the $0.3 \leq \mathrm{AOD}<0.4$ bin $(12.76 \%$ to $17.86 \%)$, and then gradually decreasing from the $0.4 \leq \mathrm{AOD}<0.5 \mathrm{bin}(12.41 \%$ to $15.90 \%)$, reaching their lowest in the AOD $>2.0 \mathrm{bin}(0.97 \%$ to $2.55 \%$ ) for the 13 cities of Jiangsu Province. Specifically, the occurrence frequencies of $0.3 \leq \mathrm{AOD}<0.4$ were comparatively highest in Wuxi $(17.86 \%)$ and lowest in Xuzhou $(12.76 \%)$, whereas the occurrence frequencies of $0.4 \leq \mathrm{AOD}<0.5$ were highest in Wuxi $(15.90 \%)$ and lowest in Lianyungang $(12.41 \%)$. For AOD $>2.0$, the occurrence frequencies were highest in Xuzhou (2.55\%), and lowest in Changzhou (0.97\%). Zhao et al. [72] conducted a similar study and reported an AOD bin of 0.0 to 0.1 , indicating extremely clean conditions and the bins of $0.3 \leq \mathrm{AOD}<0.4$ and $0.4 \leq \mathrm{AOD}<0.5$, signifying severe of aerosol extinction (scattering and absorption) in the 14 cities of Liaoning Province in Northeast China. As with annual frequency distribution, the seasonal severity of aerosol extinction in the 13 cities of Jiangsu Province, as indicated by bins of $0.3 \leq \mathrm{AOD}<0.4$ and $0.4 \leq \mathrm{AOD}<0.5$, exhibited the highest AOD occurrence frequencies in winter, followed by autumn, spring, and summer (Figure 6). A few earlier studies of seasonal AOD frequency 
distribution also reported that light and heavy aerosols were loaded in winter and spring, respectively [3,85-87]. As with the annual and seasonal frequency distributions, monthly severity of aerosol extinction, as indicated by a bin of $0.3 \leq \mathrm{AOD}<0.4$, for the 13 cities of Jiangsu Province had the highest AOD frequency occurrences in September $(20.85 \%)$ and lowest and bottommost in June (8.77\%) (Figure 7). For $0.4 \leq$ AOD $<0.5$, the highest AOD occurrence frequencies occurred in December (17.56\%) and bottommost in June $(9.49 \%)$ for the 13 cities of Jiangsu Province. Notably, monthly extreme aerosol extinction, as indicated by bin AOD > 2.0, was highest in June, fluctuating between $04.02 \%$ and $10.21 \%$ in the 13 cities of Jiangsu Province (Figure 7). The foregoing indicates that AOD values between 0.3 to 0.5 occurred comparatively often in the 13 cities of Jiangsu Province and that with increases in AOD, occurrence frequency decreased. Tiwari et al. [88] and Filonchyk et al. [89] conducted similar studies and reported that AOD values of 0.4-0.6 indicate a turbid atmosphere, which might be linked to increases in emissions and anthropogenic activity, as well as changes in meteorological circumstances.

\subsection{AOD Trends}

To gain a comprehensive understanding of changes in AOD, our study calculated both spatial and city-level trends from 2000 to 2009 and from 2010 to 2019 for the 13 cities of Jiangsu Province (Figures 8-12 and Tables S2 and S3). Tests of significance for AOD trends are indicated with black dots at a 95\% confidence level. Substantial spatial contrasts in upward AOD trends were seen for the 13 cities of Jiangsu Province from 2000 to 2009 annually and seasonally (Figure 8). Upward AOD trends were also seen for all months except May, September, November, and December, which had both upward and downward AOD trends across the study area (Figure 9). However, annually, significant upward AOD trends (per year) were varied between 0.016 to 0.028 for the 13 studied cities from 2000 to 2009, with the highest in Changzhou and Yangzhou and lowermost in Huaian (Figure 12). Seasonally, both significant and insignificant upward AOD trends (per year) were evident for all seasons in the 13 cities of Jiangsu Province from 2000 to 2009 (Table S2). Furthermore, the significant upward AOD trends (per year) were highest in both June and July, whereas those upward trends were lowest in December for all cities of Jiangsu Province except Taizhou and Zhenjiang, which had downward trends. However, these AOD trends were insignificant at a 95\% confidence level. In light of the foregoing, the increases in AOD from 2000 to 2009 in the 13 cities of Jiangsu Province could have been caused by a booming economy and industrial development, with substantial emissions of sulfur dioxide $\left(\mathrm{SO}_{2}\right)$, and primary aerosols [90,91]. In addition, Hu et al. [85] reported that rapid urbanization and burning of biomass could increase AOD.

Furthermore, a substantial spatial contrast in downward AOD trends was evident in Jiangsu Province both annually and seasonally from 2010 to 2019 (Figure 10). At the citylevel, annually significant downward AOD trends (per year) ranged from 0.019 to 0.033 , with the highest found in Zhenjiang and the lowest in Lianyungang and Suqian-except for Suzhou, which presented an insignificant downward trend of 0.018 (Figure 12). Significant and insignificant downward AOD trends (per year) were apparent in all seasons for the 13 cities of Jiangsu Province from 2010 to 2019 (Table S3). Notably, most cities in Jiangsu Province presented both significant and insignificant downward AOD trends in all months from 2010 to 2019 (Table S3). Significant downward AOD trends (per year) were found to be highest in June, whereas insignificant downward AOD trends (per year) were lowest in March for all cities of Jiangsu Province except Huaian (Figure 11). The downward AOD trends may be attributed to several factors, such as China's strict air pollution control policies, increased control of vehicular emissions, strict benzene measurement, and increased use of CNG (compressed natural gas) vehicles [73,79,85,92-94]. In addition, Ma et al. [95] and Mehta et al. [96] reported that downward AOD trends indicate a reduction in aerosol loading, which is consistent with air quality improvement over the study area. 

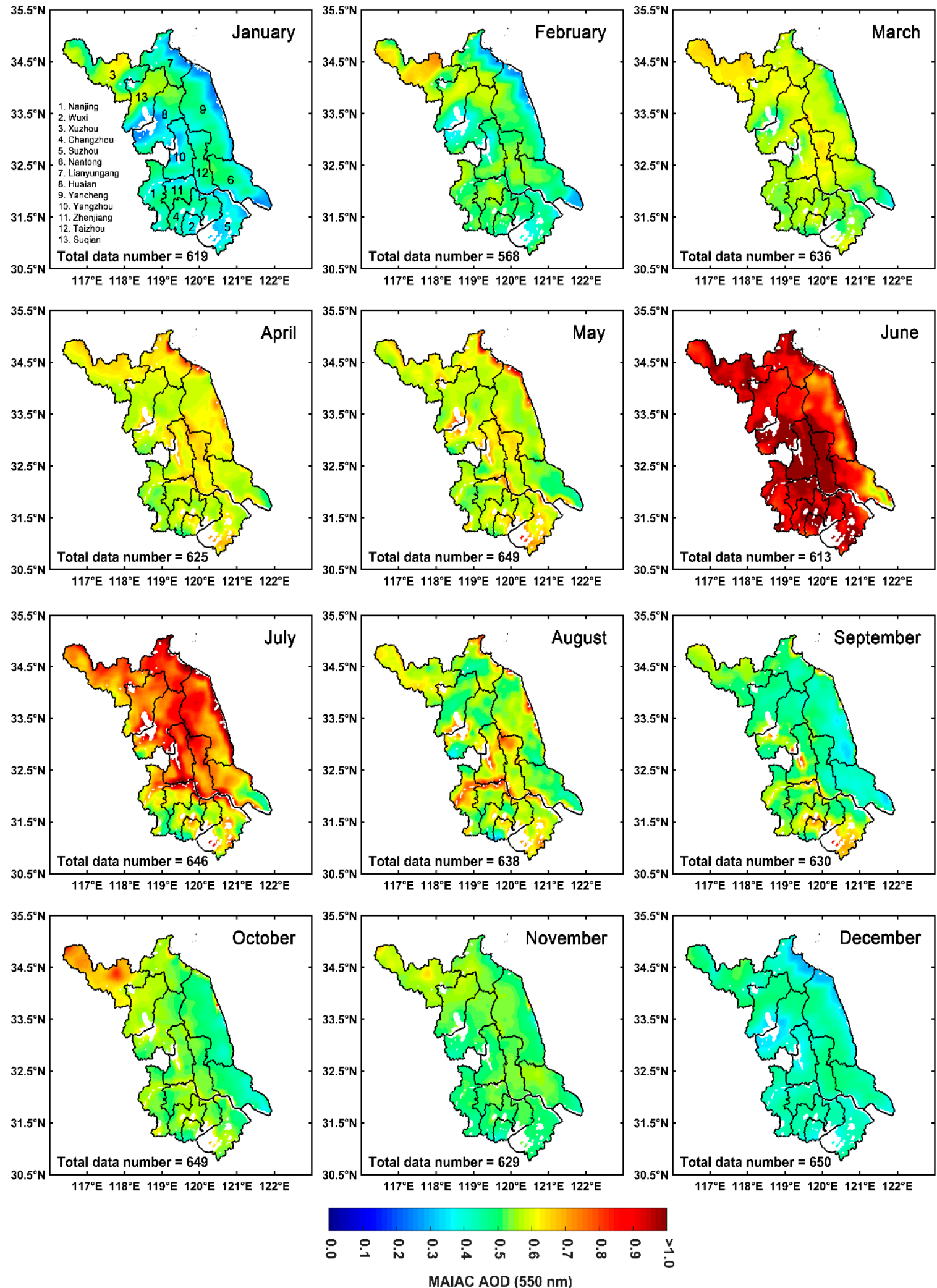

Figure 5. Monthly spatial distribution of high-resolution MODIS MAIAC AOD over Jiangsu Province from 2000 to 2020. 


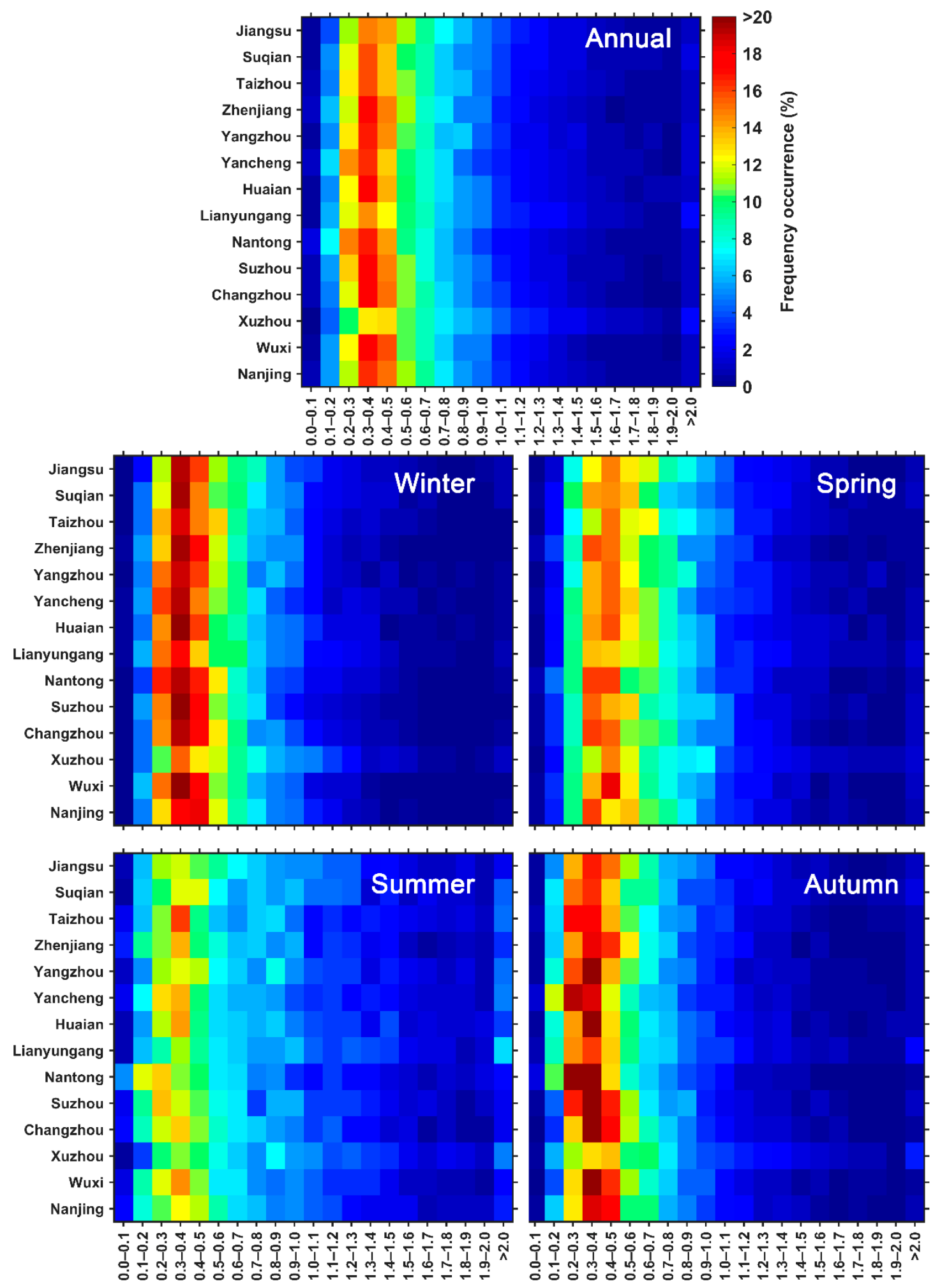

Figure 6. Annual and seasonal frequency distribution of high-resolution MODIS MAIAC AOD in 13 cities in Jiangsu Province from 2000 to 2020. 

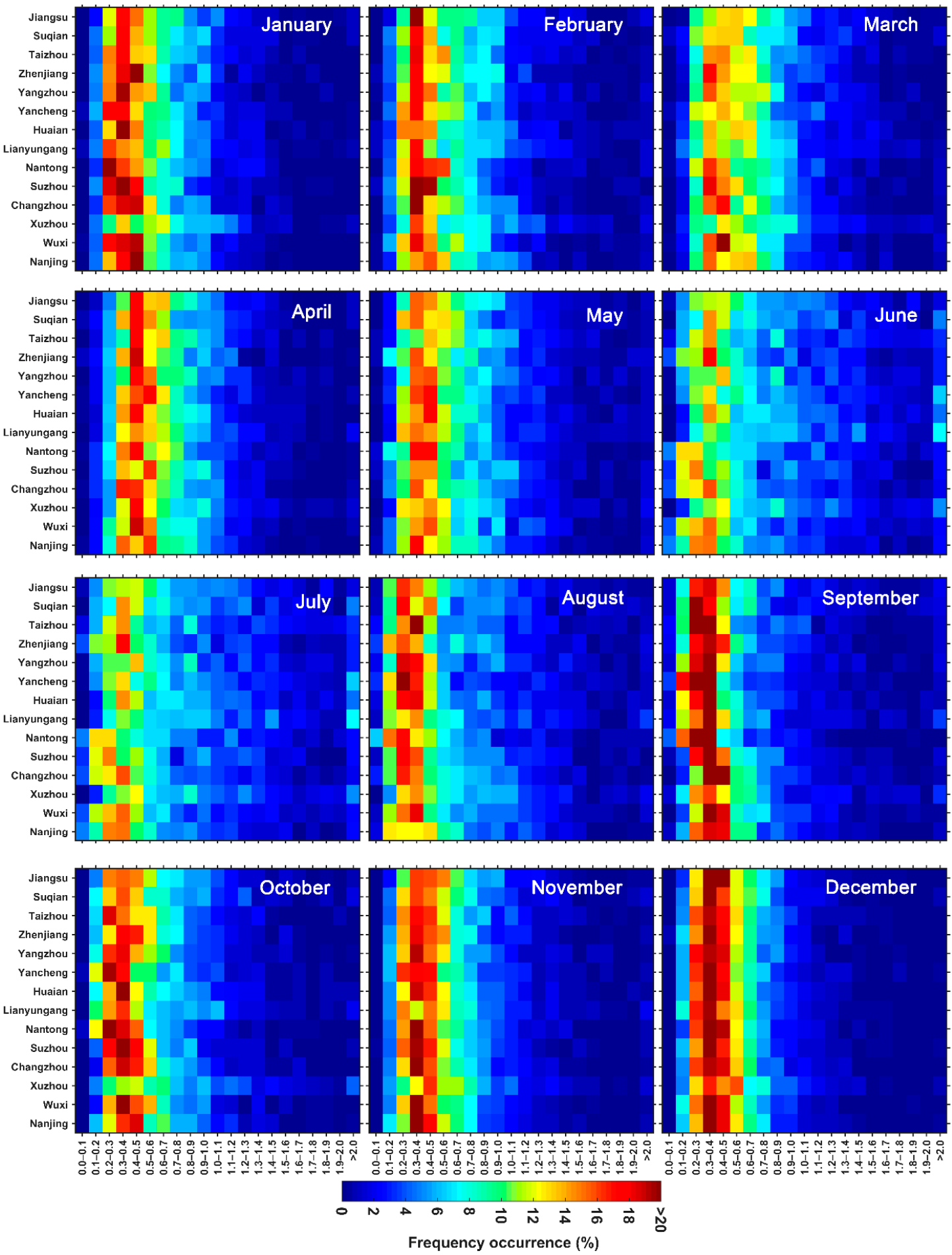

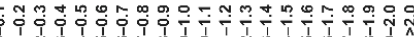

requency occurrence (\%)

Figure 7. Monthly frequency distribution of high-resolution MODIS MAIAC AOD in 13 cities in Jiangsu Province from 2000 to 2020 . 

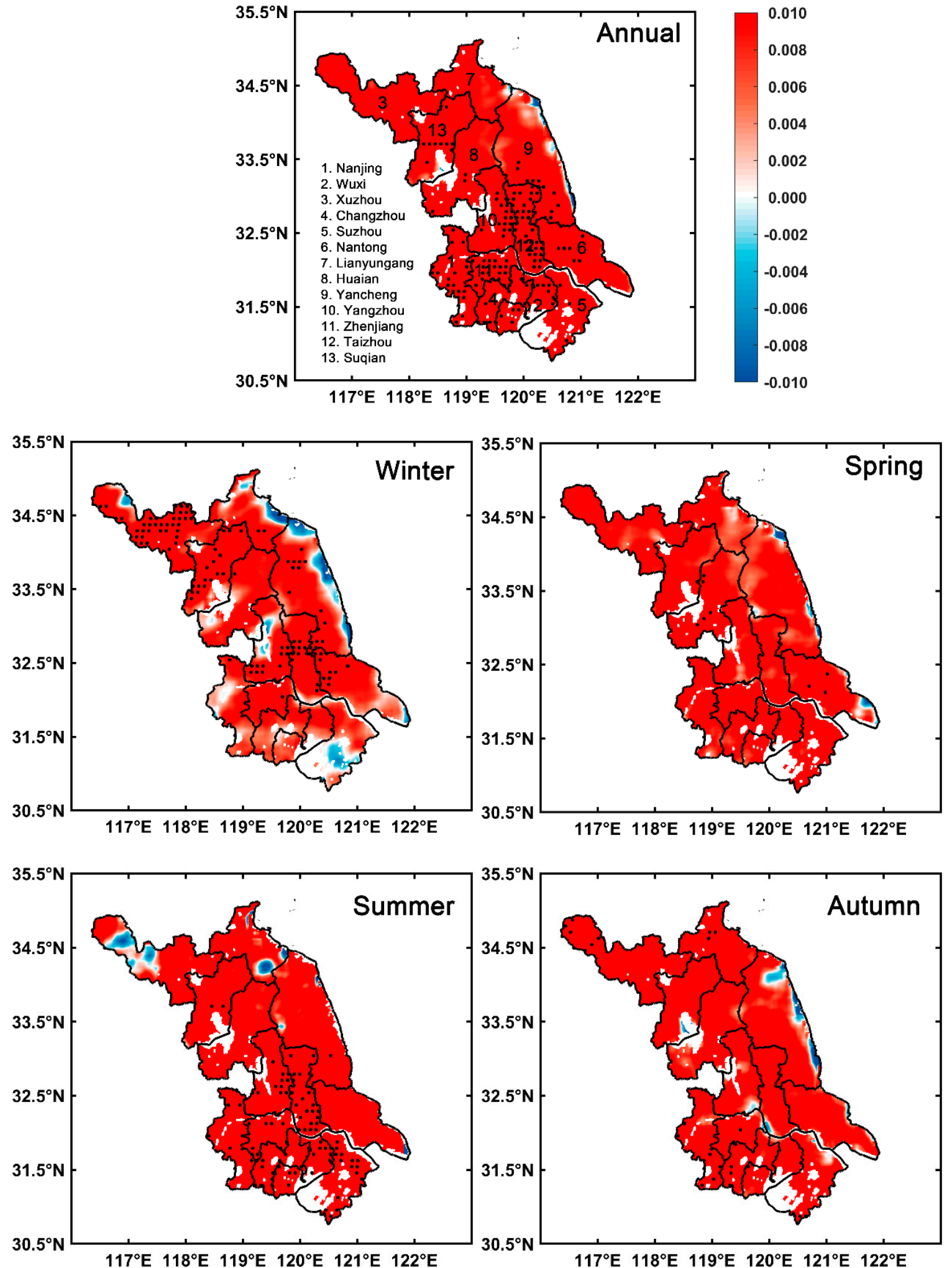

Figure 8. Annual and seasonal spatial trends of high-resolution MODIS MAIAC AOD from 2000 to 2009 in Jiangsu Province. The dot (.) symbol indicates significance at 95\% confidence interval. 

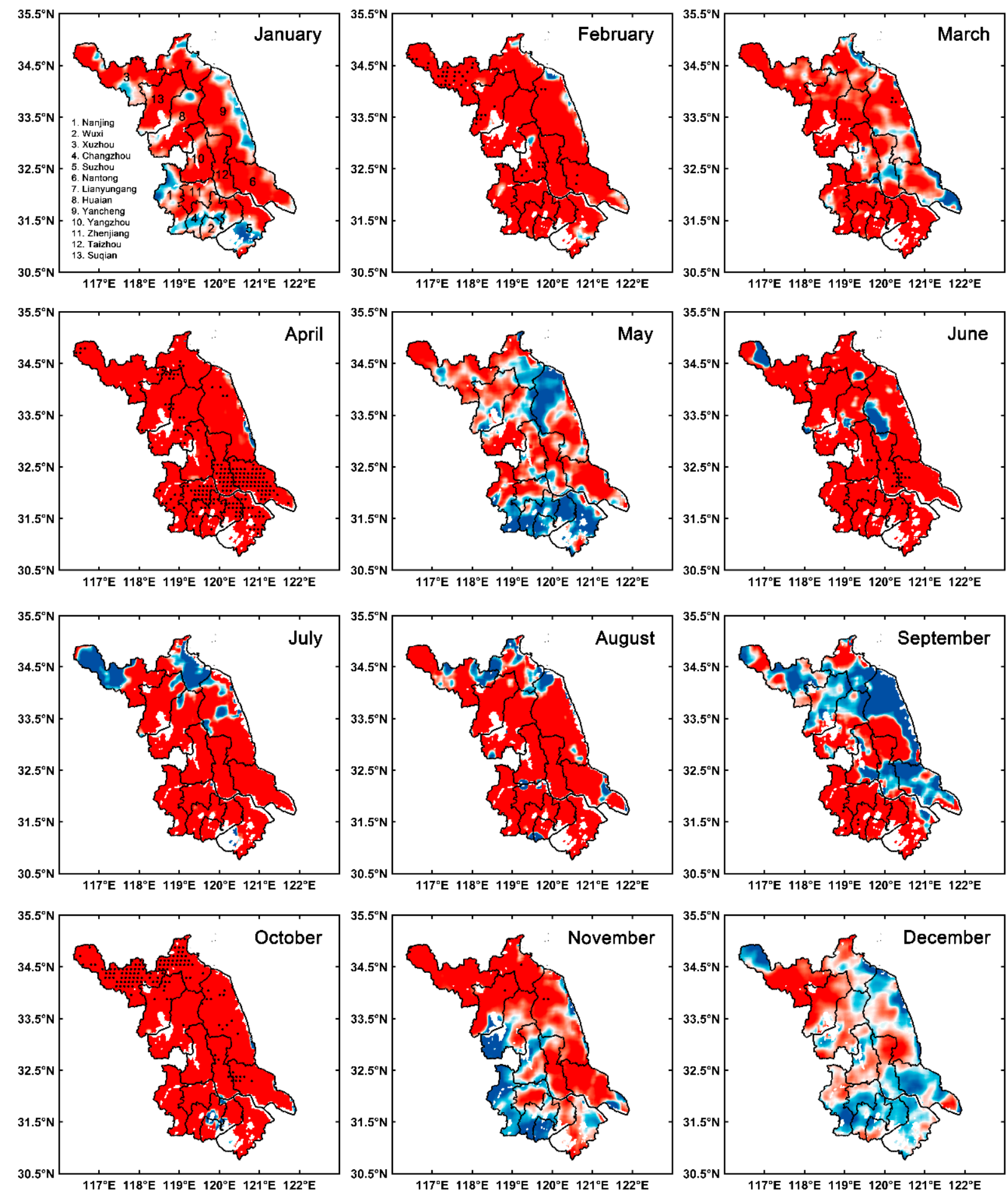

ப்

Figure 9. Monthly spatial trends of high-resolution MODIS MAIAC AOD from 2000 to 2009 in Jiangsu province. The dot (.) symbol indicates significance at $95 \%$ confidence interval. 

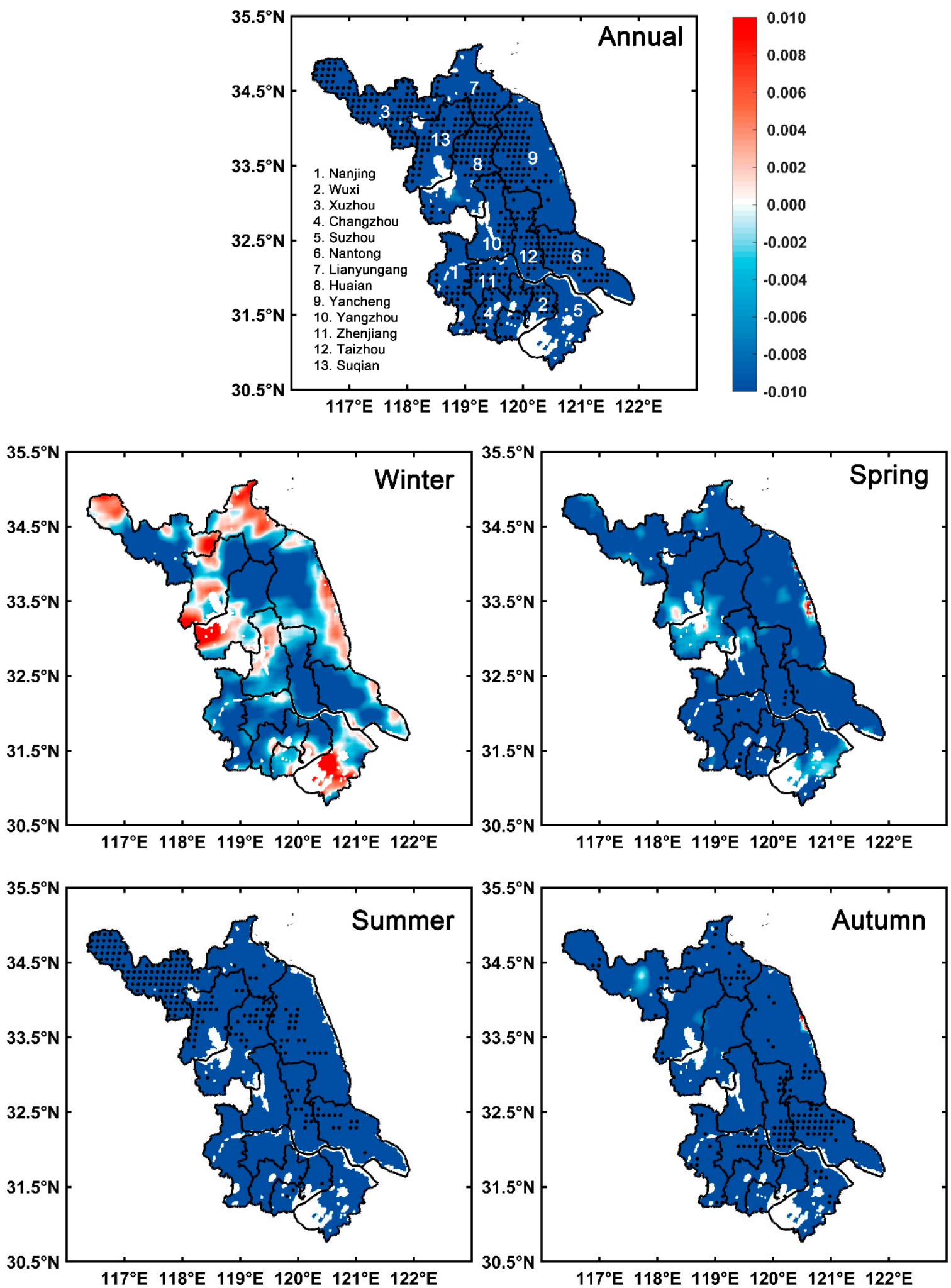

Figure 10. Annual and seasonal spatial trends of high-resolution MODIS MAIAC AOD from 2010 to 2019 in Jiangsu Province. The dot (.) symbol indicates significance at 95\% confidence interval. 

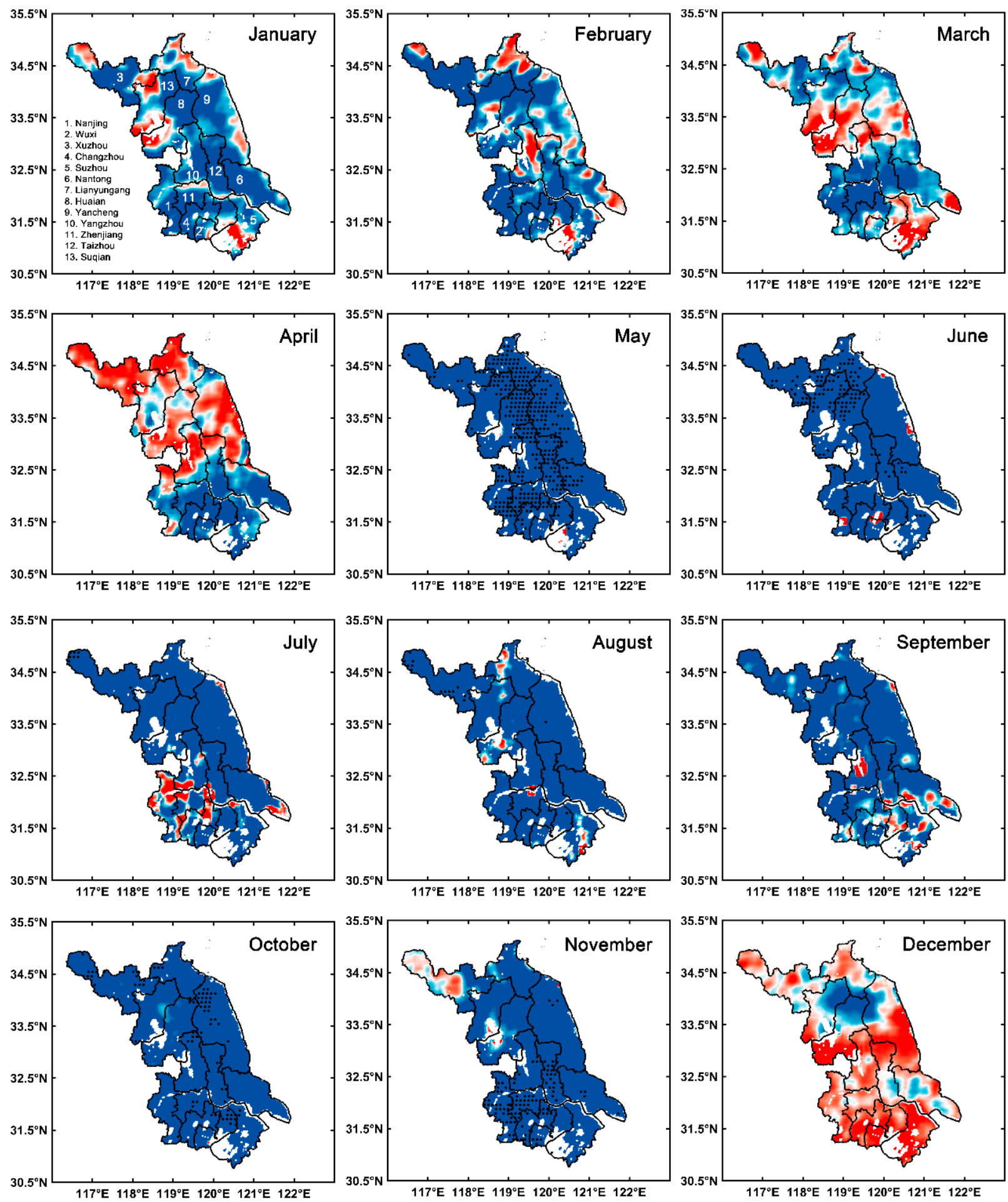

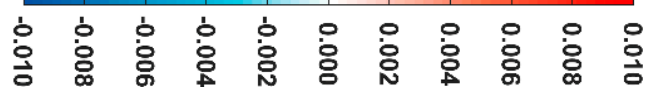

Figure 11. Monthly spatial trends of high-resolution MODIS MAIAC AOD from 2010 to 2019 in Jiangsu province. The dot (.) symbol indicates significance at $95 \%$ confidence interval. 

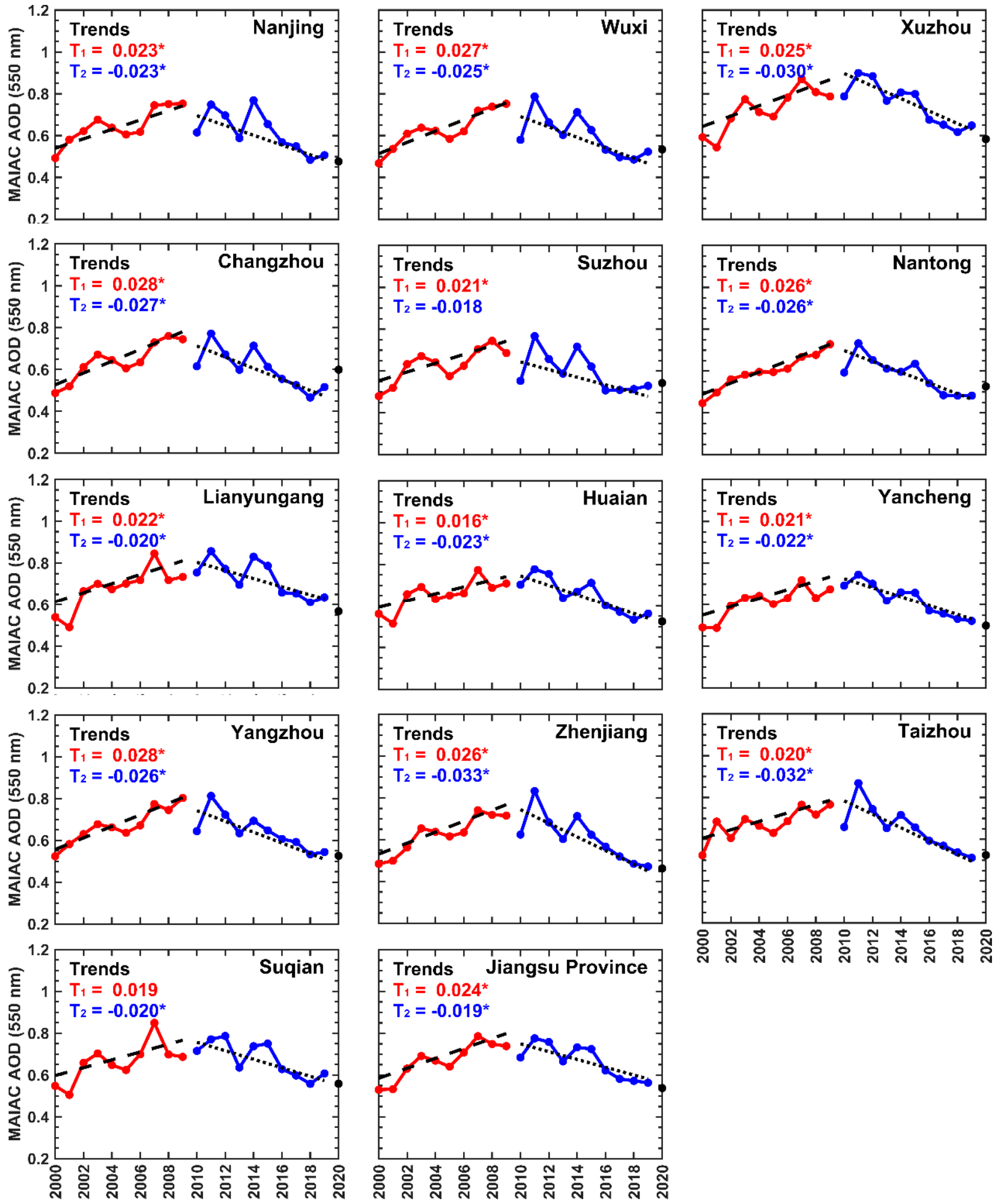

Figure 12. Trends in AOD for the periods of 2000-2009 and 2010-2019 in 13 cities in Jiangsu Province. Here, red indicates an increasing trend and blue indicates a decreasing trend of AOD. Asterisk ${ }^{*}$ ) symbol indicates significance.

\subsection{Relationship between $A O D$ and Meteorological Parameters}

To understand the relationship between AOD and meteorological parameters at seasonal scale, this study firstly discusses AOD with land surface temperature (LST), water vapor (WV), and precipitation (P) for the 13 cities of Jiangsu Province (Figure 13). In addition, the study has calculated the correlation between AOD and meteorological parameters from 2000 to 2009 and from 2010 to 2020 at a seasonal scale (Table 3). Notably, 
AOD and meteorological parameters (LST, WV, and P) showed a very similar pattern for all the cities from 2000 to 2020 (Figure 13). AOD showed insignificant positive correlations with LST in winter (0.1 0.58) and autumn (0.32 0.63) from 2000 to 2009 (Table 3), excluding spring and summer. In spring, AOD and LST showed a correlation from 0.05 to 0.75 for most cities except for Xuzhou, Lianyungang, Yancheng, Suqian, and the whole of Jiangsu (Table 3). In summer, AOD and LST also showed a correlation from 0.25 to 0.76 overJiangsu Province except for Xuzhou, Lianyungang, and Suqian (Table 3). During the 2010-2020 period, AOD and LST demonstrated mostly negative correlations over most cities of Jiangsu Province. This result is comparable with [97]. Furthermore, AOD and P (precipitation) demonstrated mostly insignificant positive correlations in all seasons over most cities from 2000 to 2009 but a negative correlation in a few areas, signifying that precipitation does not perform geographically consistent washout effects on the aerosol distribution. During the 2010-2020 period, the negative correlation between AOD and $\mathrm{P}$ was seen in winter and autumn over most cities, whereas both positive and negative correlations were found in spring and summer (Table 3). Several factors might be responsible for a weak or insignificant correlation between AOD and P over the study area. For example, atmospheric humidity leads to AOD values becoming high in summer $[78,98,99]$. MA and GUAN [100] reported that aerosol also influences the precipitation intensity. The aerosol concentration and its distribution [101], the size and properties of the aerosol particles [102-104], and monsoon circulation patterns [12,105] might be responsible for the weak correlation between AOD and precipitation. The abovementioned factors complicate the relation between AOD and precipitation and make it uncertain in different regions of China; thus, further investigations are needed in the future. Finally, AOD and WV demonstrated mostly insignificant positive correlations in winter, summer, and autumn over most cities from 2000 to 2009, whilst a negative correlation was found only in spring (Table 3). During the 2010-2020 period, insignificant negative correlations between AOD and WV were evident in winter and autumn for all 13 cities, and positive correlations appeared in spring and summer (Table 3). The stronger positive correlation in summer (signifying that the high prevalence of water vapor in summer) may boost gas-to-particle conversion and hygroscopic growth of aerosols, leading to the assembly of secondary aerosols resulting in high AOD [7,76,106,107]. Several researchers [108-111] reported that June is marked by the burning of straw and the harvesting of grain across the Yangtse River Delta, including parts of Jiangsu, which release significant amounts of aerosols, corresponding to maximum AOD (1.07) in this month. Thus, high AOD values were observed in summer, and low values in winter (Figure 13). In winter, low levels of precipitation, temperature, and water vapor may lead to low AOD throughout the study area. In addition, the Asian winter monsoon helps to reduce AOD by carrying dry and clean air into the region [73F]. Notably, AOD was found to be more impacted by meteorological parameters (LST, WV, and P) during the 2000-2009 period than in the 2010-2020 period across the 13 cities of Jiangsu Province, in line with the findings of Wang and Chen [13]. 


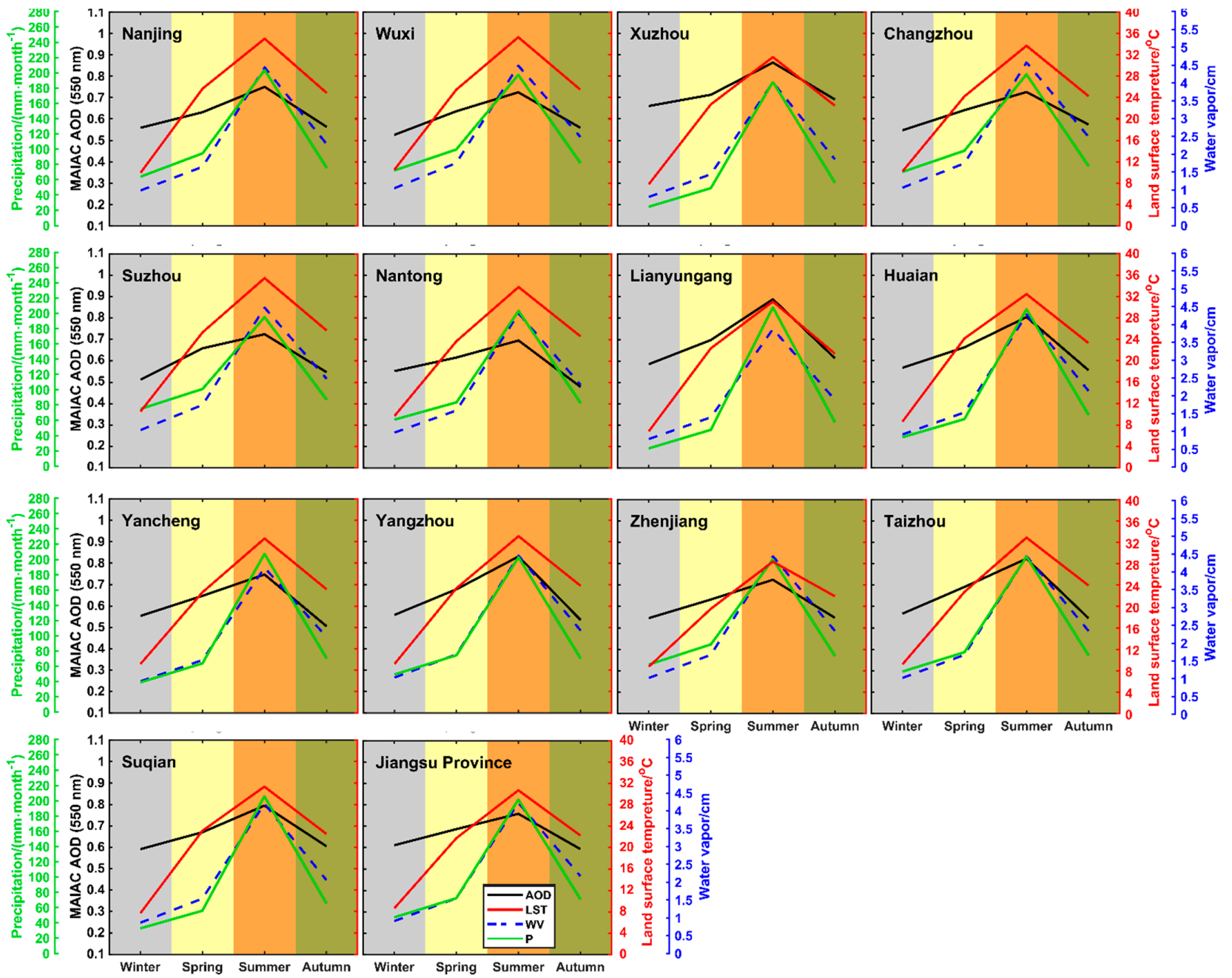

Figure 13. Meteorological impact on seasonal AOD from 2000 to 2020 in 13 cities in Jiangsu Province. 


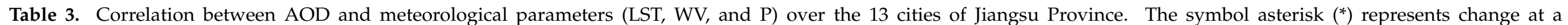
95\% significance level.

\begin{tabular}{|c|c|c|c|c|c|c|c|c|c|c|c|c|}
\hline & \multicolumn{4}{|c|}{ LST } & \multicolumn{4}{|c|}{ WV } & \multicolumn{4}{|c|}{$\mathbf{P}$} \\
\hline & Winter & Spring & Summer & Autumn & Winter & Spring & Summer & Autumn & Winter & Spring & Summer & Autumn \\
\hline \multicolumn{13}{|c|}{ 2000-2009 } \\
\hline Nanjing & 0.38 & 0.57 & 0.25 & 0.32 & 0.22 & -0.1 & 0.43 & 0.45 & 0.08 & 0.05 & 0.56 & 0.11 \\
\hline Wuxi & 0.23 & 0.49 & 0.67 * & 0.55 & 0.74 * & -0.41 & 0.31 & 0.45 & 0.31 & 0.06 & 0.55 & 0.43 \\
\hline Xuzhou & 0.1 & -0.22 & -0.53 & 0.35 & -0.11 & -0.32 & 0.43 & 0.005 & -0.33 & 0.61 & 0.24 & 0.15 \\
\hline Changzhou & 0.18 & $0.68 *$ & $0.69 *$ & 0.5 & $0.66 *$ & -0.07 & 0.42 & 0.49 & 0.4 & 0.24 & $0.66^{*}$ & 0.37 \\
\hline Suzhou & 0.36 & 0.59 & 0.6 & 0.4 & 0.58 & -0.004 & 0.11 & 0.26 & 0.22 & 0.4 & 0.08 & 0.4 \\
\hline Lianyungang & 0.15 & -0.1 & -0.27 & 0.44 & 0.19 & -0.48 & 0.64 * & 0.34 & -0.33 & $0.71 *$ & -0.06 & 0.54 \\
\hline Huaian & 0.49 & 0.05 & 0.52 & 0.43 & 0.37 & -0.37 & $0.79 *$ & 0.24 & -0.25 & 0.6 & 0.22 & 0.44 \\
\hline Yancheng & 0.15 & -0.21 & 0.41 & 0.35 & 0.53 & -0.39 & 0.70 * & 0.1 & -0.11 & 0.52 & 0.05 & 0.54 \\
\hline Yangzhou & 0.25 & 0.46 & 0.6 & 0.63 & 0.57 & -0.15 & 0.48 & 0.23 & 0.11 & 0.25 & 0.26 & 0.3 \\
\hline Zhenjiang & 0.58 & 0.56 & 0.25 & 0.5 & 0.36 & -0.18 & 0.53 & 0.24 & -0.01 & 0.02 & $0.70 *$ & 0.48 \\
\hline Taizhou & 0.37 & 0.25 & 0.3 & 0.55 & 0.53 & -0.1 & 0.35 & 0.24 & 0.07 & 0.23 & 0.3 & 0.59 \\
\hline Suqian & 0.22 & -0.26 & -0.2 & 0.51 & 0.18 & -0.32 & 0.78 * & 0.21 & -0.14 & 0.63 & 0.15 & 0.46 \\
\hline Jiangsu & 0.18 & -0.06 & 0.38 & 0.6 & 0.61 & -0.15 & 0.61 & 0.17 & 0.09 & 0.38 & 0.14 & 0.53 \\
\hline \multicolumn{13}{|c|}{$2010-2020$} \\
\hline Wuxi & -0.09 & -0.15 & -0.49 & -0.48 & -0.25 & 0.26 & 0.19 & -0.28 & $-0.64 *$ & -0.16 & 0.36 & -0.37 \\
\hline Xuzhou & -0.36 & -0.1 & $-0.60 *$ & $-0.62^{*}$ & -0.5 & 0.1 & -0.07 & -0.23 & -0.57 & -0.22 & -0.58 & 0.05 \\
\hline Changzhou & 0.08 & -0.16 & $-0.75 *$ & -0.44 & 0.001 & 0.004 & 0.25 & -0.45 & -0.69 * & -0.12 & 0.47 & -0.21 \\
\hline Suzhou & -0.25 & 0.04 & -0.56 & -0.36 & -0.2 & 0.33 & 0.14 & -0.31 & -0.59 & -0.5 & 0.46 & -0.53 \\
\hline Nantong & -0.12 & -0.15 & $-0.77^{*}$ & -0.25 & -0.3 & -0.06 & 0.42 & -0.52 & -0.44 & -0.11 & 0.36 & -0.4 \\
\hline Lianyungang & -0.34 & 0.28 & -0.43 & -0.71 * & -0.59 & 0.24 & 0.06 & -0.13 & -0.60 * & -0.001 & -0.19 & 0.38 \\
\hline Huaian & -0.13 & 0.03 & -0.73 * & -0.59 & -0.31 & 0.37 & 0.08 & -0.23 & -0.62 * & 0.25 & 0.02 & -0.13 \\
\hline Yancheng & -0.16 & -0.09 & -0.59 & -0.70 * & -0.48 & 0.22 & 0.36 & -0.13 & $-0.76^{*}$ & 0.18 & -0.08 & -0.11 \\
\hline Yangzhou & -0.1 & 0.05 & -0.48 & -0.47 & -0.09 & 0.27 & 0.43 & -0.38 & -0.61 * & -0.05 & 0.14 & -0.04 \\
\hline Zhenjiang & 0.09 & -0.04 & 0.29 & -0.27 & -0.29 & 0.31 & 0.27 & -0.31 & -0.73 * & 0.09 & 0.15 & 0.08 \\
\hline Taizhou & -0.36 & -0.25 & -0.6 & $-0.77^{*}$ & -0.36 & 0.2 & 0.42 & -0.24 & -0.67 * & 0.01 & 0.28 & -0.2 \\
\hline Suqian & 0.15 & -0.02 & -0.34 & $-0.68 *$ & -0.3 & 0.54 & 0.05 & -0.31 & -0.62 * & 0.09 & -0.1 & -0.11 \\
\hline Jiangsu & -0.39 & -0.02 & -0.58 & $-0.71^{*}$ & -0.58 & 0.27 & 0.11 & -0.35 & -0.59 & 0.06 & 0.08 & -0.23 \\
\hline
\end{tabular}




\section{Conclusions}

We based this paper on MODIS level 2 high-resolution (1 km) MAIAC AOD (550 nm) from the Terra and Aqua satellites for 2000-2020, evaluated against ground-based AERONET data across three sites (Xuzhou-CUMT, NUIST, and Taihu) in Jiangsu Province. We also examined the spatiotemporal distributions of and variations in AOD, frequency distributions, and trends, while exploring the impact of meteorology on AOD in the 13 cities of Jiangsu Province. Our major findings are as follows:

- The evaluation study showed a consistent result between the MAIAC AOD and AERONET AOD with a high Pearson's correlation coefficient (r: 0.867 0.929), and lower RMSE (0.130 0.287) and MAE (0.091 0.198). These findings indicate that MODIS high-resolution MAIAC aerosol products can effectively reveal city-level aerosol pollution scenarios.

- The spatial distribution of annual mean AOD showed high values (over 0.60) in most cities, excluding the southeast of Nantong City, which was characterized by a low AOD value $(<0.40)$. Moreover, the 21 -year city-level annual mean AOD was highest in Xuzhou $(0.73 \pm 0.10)$ and lowest in Nantong $(0.59 \pm 0.08)$.

- The spatial distribution of seasonal mean AOD showed higher values in summer $(>0.70)$ than in spring, autumn, and winter for most cities. In particular, the 21-year city-level summer mean AOD was highest in Lianyungang $(0.89 \pm 0.24)$ and lowest in Nantong $(0.70 \pm 0.18)$, whereas the spring mean AOD was highest in Xuzhou $(0.71 \pm 0.09)$ and lowest in Nantong $(0.62 \pm 0.08)$. The autumn mean AOD was also highest in Xuzhou $(0.69 \pm 0.12)$ and lowest in Nantong $(0.48 \pm 0.08)$, whereas winter AOD was highest in Xuzhou (0.66 \pm 0.10$)$ and lowest in Suzhou (0.51 \pm 0.08$)$. Furthermore, the spatial mean AOD peaked in June $(>0.9)$ and was lowest in December $(<0.4)$ throughout Jiangsu Province.

- The occurrence frequencies of $0.3 \leq \mathrm{AOD}<0.4$ and $0.4 \leq \mathrm{AOD}<0.5$ were commonly observed, indicating a turbid atmosphere, perhaps associated with anthropogenic activities, increased emissions, and changes in meteorological circumstances.

- Annually, significant upward AOD trends ranged from 0.016 to 0.028 (per year) in all the 13 cities during 2000-2009, being highest in Changzhou and Yangzhou and lowest in Huaian. Moreover, for 2010-2019, annually, significant downward AOD trends (per year) varied between 0.020 and 0.033 , being highest in Zhenjiang and lowermost in Lianyungang and Suqian. These downward trends indicate the enhancement of air quality throughout the study area, perhaps because of implementing China's strict air pollution control policies and proper control of vehicular emissions.

- The AOD and meteorological parameters (LST, WV, and P) presented a very similar pattern, signifying that meteorology plays a role in AOD.

Supplementary Materials: The following are available online at https://www.mdpi.com/article/ 10.3390/rs13142842/s1, Figure S1: Monthly variations of high-resolution MODIS MAIAC AOD in 13 cities in Jiangsu Province from 2000 to 2020. Table S1: Evaluation of high-resolution (1 km) MODIS MAIAC AOD against AERONET AOD over NUIST, Taihu, and Xuzhou-CUMT sites located in Jiangsu Province from 2000 to 2020. Table S2: City-level trends of high-resolution MODIS MAIAC AOD in Jiangsu province from 2000 to 2009. The symbol asterisk $\left(^{*}\right)$ represents change at a $95 \%$ significant level. Table S3: City-level trends of high-resolution MODIS MAIAC AOD in Jiangsu province from 2010 to 2019 . The symbol asterisk $\left(^{*}\right)$ represents change at a $95 \%$ significant level.

Author Contributions: Conceptualization, Data curation, Methodology, Formal analysis, Investigation, Validation, Visualization, Writing-original draft, Y.W., M.A.A.; Supervision, Investigation, Writing-review and editing, M.B.; Supervision, Investigation, Validation, Visualization, Writingreview and editing, Z.Q.; Writing-review and editing, M.A.; Data curation, S.K., Y.Z., M.M.I. All authors have read and agreed to the published version of the manuscript.

Funding: The National Key Research and Development Program of China (2016YFC1400901), the National Natural Science Foundation (U1901215), the Marine Special Program of Jiangsu Province 
in China (JSZRHYKJ202007), and Jiangsu Technology Project of Nature Resources (KJXM2019042), funded this research.

Institutional Review Board Statement: Not applicable.

Informed Consent Statement: Not Applicable.

Data Availability Statement: Data available on request.

Acknowledgments: The authors are grateful to NASA for providing satellite-based Aerosol Optical Depth (AOD), Land Surface Temperature (LST), Water Vapor (WV), Precipitation (P), and Normalized Difference Vegetation Index (NDVI). The second author (Md. Arfan Ali) contributed equally, and is highly grateful to the China Scholarship Council (CSC) and NUIST for granting his fellowship and providing the required support.

Conflicts of Interest: All authors declare that there is not any personal or financial conflict of interest.

\section{References}

1. Ali, A.; Islam, M.; Islam, N.; Almazroui, M. Investigations of MODIS AOD and cloud properties with CERES sensor based net cloud radiative effect and a NOAA HYSPLIT Model over Bangladesh for the period 2001-2016. Atmos. Res. 2019, 215, 268-283. [CrossRef]

2. Ali, A.; Assiri, M.; Dambul, R. Seasonal Aerosol Optical Depth (AOD) Variability Using Satellite Data and its Comparison over Saudi Arabia for the Period 2002-2013. Aerosol. Air Qual. Res. 2017, 17, 1267-1280. [CrossRef]

3. Wei, J.; Sun, L. Comparison and Evaluation of Different MODIS Aerosol Optical Depth Products Over the Beijing-Tianjin-Hebei Region in China. IEEE J. Sel. Top. Appl. Earth Obs. Remote. Sens. 2016, 10, 835-844. [CrossRef]

4. Bilal, M.; Nichol, J.E.; Nazeer, M. Validation of Aqua-MODIS C051 and C006 Operational Aerosol Products Using AERONET Measurements Over Pakistan. IEEE J. Sel. Top. Appl. Earth Obs. Remote. Sens. 2015, 9, 2074-2080. [CrossRef]

5. Deng, X.; Shi, C.; Wu, B.; Chen, Z.; Nie, S.; He, D.; Zhang, H. Analysis of aerosol characteristics and their relationships with meteorological parameters over Anhui province in China. Atmos. Res. 2012, 109-110, 52-63. [CrossRef]

6. Tan, C.; Zhao, T.; Xu, X.; Liu, J.; Zhang, L.; Tang, L. Climatic analysis of satellite aerosol data on variations of submicron aerosols over East China. Atmos. Environ. 2015, 123, 392-398. [CrossRef]

7. Butt, M.J.; Assiri, M.E.; Ali, A. Assessment of AOD variability over Saudi Arabia using MODIS Deep Blue products. Environ. Pollut. 2017, 231, 143-153. [CrossRef]

8. Pope, C.A., III; Dockery, D.W. Health Effects of Fine Particulate Air Pollution: Lines that Connect. J. Air Waste Manag. Assoc. 2006, 56, 709-742. [CrossRef]

9. Schwartz, S.E.; Andreae, M. Uncertainty in Climate Change Caused by Aerosols. Science 1996, 272, 1121. [CrossRef]

10. Menon, S.; Hansen, J.; Nazarenko, L.; Luo, Y. Climate Effects of Black Carbon Aerosols in China and India. Science 2002, 297, 2250-2253. [CrossRef]

11. Ackerman, A.S.; Kirkpatrick, M.; Stevens, D.E.; Toon, O.B. The impact of humidity above stratiform clouds on indirect aerosol climate forcing. Nature 2004, 432, 1014-1017. [CrossRef]

12. IPCC Working Group 1; Stocker, T.F.; Qin, D.; Plattner, G.-K.; Tignor, M.; Allen, S.K.; Boschung, J.; Nauels, A.; Xia, Y.; Bex, V.; et al. IPCC, 2013: Climate Change 2013: The Physical Science Basis. Contribution of Working Group I to the Fifth Assessment Report of the Intergovernmental Panel on Climate Change; IPCC: Geneva, Switzerland, 2013.

13. Ackerman, T.P.; Toon, O.B. Absorption of visible radiation in atmosphere containing mixtures of absorbing and nonabsorbing particles. Appl. Opt. 1981, 20, 3661-3668. [CrossRef] [PubMed]

14. Charlson, R.J.; Schwartz, S.E.; Hales, J.M.; Cess, R.D.; Coakley, J.A.; Hansen, J.E.; Hofmann, D.J. Climate Forcing by Anthropogenic Aerosols. Science 1992, 255, 423-430. [CrossRef] [PubMed]

15. Ramanathan, V.; Crutzen, P.J.; Kiehl, J.T.; Rosenfeld, D. Atmosphere: Aerosols, climate, and the hydrological cycle. Science 2001, 294, 2119-2124. [CrossRef] [PubMed]

16. Ackerman, A.S.; Toon, O.B.; Stevens, D.E.; Heymsfield, A.J.; Ramanathan, V.; Welton, E.J. Reduction of Tropical Cloudiness by Soot. Science 2000, 288, 1042-1047. [CrossRef] [PubMed]

17. Twomey, S.A.; Piepgrass, M.; Wolfe, T.L. An assessment of the impact of pollution on global cloud albedo. Tellus B Chem. Phys. Meteorol. 1984, 36, 356-366. [CrossRef]

18. Dubovik, O.; Holben, B.; Eck, T.F.; Smirnov, A.; Kaufman, Y.J.; King, M.D.; Tanré, D.; Slutsker, I. Variability of ab-sorption and optical properties of key aerosol types observed in worldwide locations. J. Atmos. Sci. 2002, 59, 590-608. [CrossRef]

19. Eck, T.F.; Holben, B.N.; Dubovik, O.; Smirnov, A.; Goloub, P.; Chen, H.B.; Chatenet, B.; Gomes, L.; Zhang, X.-Y.; Tsay, S.-C.; et al. Columnar aerosol optical properties at AERONET sites in central eastern Asia and aerosol transport to the tropical mid-Pacific. J. Geophys. Res. Space Phys. 2005, 110, 1-18. [CrossRef]

20. Bréon, F.-M.; Tanré, D.; Generoso, S. Aerosol Effect on Cloud Droplet Size Monitored from Satellite. Science 2002, 295, 834-838. [CrossRef] 
21. Che, H.; Gui, K.; Xia, X.; Wang, Y.; Holben, B.N.; Goloub, P.; Cuevas-Agulló, E.; Wang, H.; Zheng, Y.; Zhao, H.; et al. Large contribution of meteorological factors to inter-decadal changes in regional aerosol optical depth. Atmos. Chem. Phys. Discuss. 2019, 19, 10497-10523. [CrossRef]

22. Zhao, H.; Che, H.; Xia, X.; Wang, Y.; Wang, H.; Wang, P.; Ma, Y.; Yang, H.; Liu, Y.; Wang, Y.; et al. Multiyear Ground-Based Measurements of Aerosol Optical Properties and Direct Radiative Effect Over Different Surface Types in Northeastern China. J. Geophys. Res. Atmos. 2018, 123, 13-887. [CrossRef]

23. Holben, B.; Eck, T.; Slutsker, I.; Tanré, D.; Buis, J.; Setzer, A.; Vermote, E.; Reagan, J.; Kaufman, Y.; Nakajima, T.; et al. AERONET—A Federated Instrument Network and Data Archive for Aerosol Characterization. Remote Sens. Environ. 1998, 66, 1-16. [CrossRef]

24. Xia, X.; Che, H.; Shi, H.; Chen, H.; Zhang, X.; Wang, P.; Goloub, P.; Holben, B. Advances in sunphotometer-measured aerosol optical properties and related topics in China: Impetus and perspectives. Atmos. Res. 2021, 249. [CrossRef]

25. Almazroui, M. A comparison study between AOD data from MODIS deep blue collections 51 and 06 and from AERONET over Saudi Arabia. Atmos. Res. 2019, 225, 88-95. [CrossRef]

26. Bokoye, A.; Royer, A.; O’Neil, N.; Cliche, P.; Fedosejevs, G.; Teillet, P.; McArthur, L. Characterization of atmospheric aerosols across Canada from a ground-based sunphotometer network: AEROCAN. Atmos. Ocean 2001, 39, 429-456. [CrossRef]

27. Holben, B.N.; Tanré, D.; Smirnov, A.; Eck, T.F.; Slutsker, I.; Abuhassan, N.; Newcomb, W.W.; Schafer, J.S.; Chatenet, B.; Lavenu, F.; et al. An emerging ground-based aerosol climatology: Aerosol optical depth from AERONET. J. Geophys. Res. Space Phys. 2001, 106, 12067-12097. [CrossRef]

28. Xin, J.; Wang, Y.; Li, Z.; Wang, P.; Hao, W.M.; Nordgren, B.L.; Wang, S.; Liu, G.; Wang, L.; Wen, T.; et al. Aerosol optical depth (AOD) and Ångström exponent of aerosols observed by the Chinese Sun Hazemeter Network from August 2004 to September 2005. J. Geophys. Res. Space Phys. 2007, 112. [CrossRef]

29. Torres, O.; Bhartia, P.K.; Herman, J.R.; Sinyuk, A.; Ginoux, P.; Holben, B. A long-term record of aerosol optical depth from TOMS observations and comparison to AERONET measurements. J. Atmos. Sci. 2002, 59, 398-413. [CrossRef]

30. Hauser, A.; Oesch, D.; Foppa, N.; Wunderle, S. NOAA AVHRR derived aerosol optical depth over land. J. Geophys. Res. Space Phys. 2005, 110. [CrossRef]

31. Remer, L.A.; Kaufman, Y.J.; Tanré, D.; Mattoo, S.; Chu, D.A.; Martins, J.V.; Li, R.R.; Ichoku, C.; Levy, R.C.; Kleidman, R.G.; et al. The MODIS Aerosol Algorithm, Products, and Validation. J. Atmos. Sci. 2005, 62, 947-973. [CrossRef]

32. Hsu, N.C.; Jeong, M.-J.; Bettenhausen, C.; Sayer, A.; Hansell, R.; Seftor, C.S.; Huang, J.; Tsay, S.-C. Enhanced Deep Blue aerosol retrieval algorithm: The second generation. J. Geophys. Res. Atmos. 2013, 118, 9296-9315. [CrossRef]

33. Levy, R.C.; A Remer, L.; Kleidman, R.; Mattoo, S.K.; Ichoku, C.; A Kahn, R.; Eck, T.F. Global evaluation of the Collection 5 MODIS dark-target aerosol products over land. Atmos. Chem. Phys. Discuss. 2010, 10, 10399-10420. [CrossRef]

34. Lyapustin, A.; Martonchik, J.; Wang, Y.; Laszlo, I.; Korkin, S. Multiangle implementation of atmospheric correction (MAIAC): 1. Radiative transfer basis and look-up tables. J. Geophys. Res. Space Phys. 2011, 116. [CrossRef]

35. Torres, O.; Tanskanen, A.; Veihelmann, B.; Ahn, C.; Braak, R.; Bhartia, P.K.; Veefkind, P.; Levelt, P. Aerosols and sur-face UV products form Ozone Monitoring Instrument observations: An overview. J. Geophys. Res. Atmos. 2007, 112. [CrossRef]

36. Sayer, A.; Hsu, N.C.; Bettenhausen, C.; Jeong, M.-J.; Holben, B.N.; Zhang, J. Global and regional evaluation of over-land spectral aerosol optical depth retrievals from SeaWiFS. Atmos. Meas. Tech. 2012, 5, 1761-1778. [CrossRef]

37. Chudnovsky, A.A.; Lee, H.J.; Kostinski, A.; Kotlov, T.; Koutrakis, P. Prediction of daily fine particulate matter concentrations using aerosol optical depth retrievals from the Geostationary Operational Environmental Satellite (GOES). J. Air Waste Manag. Assoc. 2012, 62, 1022-1031. [CrossRef]

38. Choi, J.-K.; Park, Y.J.; Ahn, J.H.; Lim, H.-S.; Eom, J.; Ryu, J.-H. GOCI, the world's first geostationary ocean color observation satellite, for the monitoring of temporal variability in coastal water turbidity. J. Geophys. Res. Space Phys. 2012, 117. [CrossRef]

39. Liu, H.; Remer, L.A.; Huang, J.; Huang, H.-C.; Kondragunta, S.; Laszlo, I.; Oo, M.; Jackson, J.M. Preliminary evaluation of S-NPP VIIRS aerosol optical thickness. J. Geophys. Res. Atmos. 2014, 119, 3942-3962. [CrossRef]

40. Chu, D.A.; Kaufman, Y.J.; Ichoku, C.; Remer, L.A.; Tanré, D.; Holben, B.N.; Chu, D.A.; Kaufman, Y.J.; Ichoku, C.; Remer, L.A.; et al. Validation of MODIS aerosol optical depth retrieval over land. Geophys. Res. Lett. 2002, 29, 1-2. [CrossRef]

41. Remer, L.A.; Kaufman, Y.J.; Ichoku, C.; Mattoo, S.; Chu, D.A.; Holben, B.; Dubovik, O.; Martins, J.V.; Li, R.; Tanré, D.; et al. Validation of MODIS aerosol retrieval over ocean. Geophys. Res. Lett. 2002, 29. [CrossRef]

42. Levy, R.C.; Mattoo, S.; Munchak, L.A.; Remer, L.A.; Sayer, A.M.; Patadia, F.; Hsu, N.C. The Collection 6 MODIS aerosol products over land and ocean. Atmos. Meas. Tech. 2013, 6, 2989-3034. [CrossRef]

43. Kaufman, Y.J.; Tanré, D.; Remer, L.A.; Vermote, E.F.; Chu, A.; Holben, B.N. Operational remote sensing of tropospheric aerosol over land from EOS moderate resolution imaging spectroradiometer. J. Geophys. Res. Space Phys. 1997, 102, 17051-17067. [CrossRef]

44. Hsu, N.C.; Tsay, S.-C.; King, M.D.; Herman, J.R. Deep Blue Retrievals of Asian Aerosol Properties During ACE-Asia. IEEE Trans. Geosci. Remote Sens. 2006, 44, 3180-3195. [CrossRef]

45. Lyapustin, A.; Wang, Y.; Laszlo, I.; Kahn, R.; Korkin, S.; Remer, L.; Levy, R.; Reid, J.S. Multiangle implementation of atmospheric correction (MAIAC): 2. Aerosol algorithm. J. Geophys. Res. Space Phys. 2011, 116. [CrossRef]

46. Lyapustin, A.; Wang, Y.; Korkin, S.; Huang, D. MODIS Collection 6 MAIAC algorithm. Atmos. Meas. Tech. 2018, 11, 5741-5765. [CrossRef] 
47. Kahn, R.A.; Nelson, D.L.; Garay, M.J.; Levy, R.; Bull, M.A.; Diner, D.J.; Martonchik, J.V.; Paradise, S.R.; Hansen, E.G.; Remer, L.A. MISR Aerosol Product Attributes and Statistical Comparisons With MODIS. IEEE Trans. Geosci. Remote Sens. 2009, 47, $4095-4114$. [CrossRef]

48. Smirnov, A.; Holben, B.; Eck, T.; Dubovik, O.; Slutsker, I. Cloud-Screening and Quality Control Algorithms for the AERONET Database. Remote Sens. Environ. 2000, 73, 337-349. [CrossRef]

49. Martins, V.S.; Lyapustin, A.; Wang, Y.; Giles, D.M.; Smirnov, A.; Slutsker, I.; Korkin, S. Global validation of columnar water vapor derived from EOS MODIS-MAIAC algorithm against the ground-based AERONET observations. Atmos. Res. 2019, 225, 181-192. [CrossRef]

50. Remer, L.A.; Mattoo, S.K.; Levy, R.C.; Munchak, L.A. MODIS 3 km aerosol product: Algorithm and global perspective. Atmos. Meas. Tech. 2013, 6, 1829-1844. [CrossRef]

51. Zhang, J.; Reid, J.S.; Alfaro-Contreras, R.; Xian, P. Has China been exporting less particulate air pollution over the past decade? Geophys. Res. Lett. 2017, 44, 2941-2948. [CrossRef]

52. Martins, V.S.; Lyapustin, A.; Carvalho, L.A.S.; Barbosa, C.C.F.; Novo, E.M.L.M. Validation of high-resolution MAIAC aerosol product over South America. J. Geophys. Res. Atmos. 2017, 122, 7537-7559. [CrossRef]

53. Superczynski, S.D.; Kondragunta, S.; Lyapustin, A.I. Evaluation of the Multi-Angle Implementation of Atmospheric Correction (MAIAC) Aerosol Algorithm through Intercomparison with VIIRS Aerosol Products and AERONET. J. Geophys. Res. Atmos. 2017, 122, 3005-3022. [CrossRef]

54. Mhawish, A.; Banerjee, T.; Sorek-Hamer, M.; Lyapustin, A.; Broday, D.M.; Chatfield, R. Comparison and evaluation of MODIS Multi-angle Implementation of Atmospheric Correction (MAIAC) aerosol product over South Asia. Remote Sens. Environ. 2019, 224, 12-28. [CrossRef]

55. Liu, N.; Zou, B.; Feng, H.; Wang, W.; Tang, Y.; Liang, Y. Evaluation and comparison of multiangle implementation of the atmospheric correction algorithm, Dark Target, and Deep Blue aerosol products over China. Atmos. Chem. Phys. Discuss. 2019, 19, 8243-8268. [CrossRef]

56. Zhang, Z.; Wu, W.; Fan, M.; Wei, J.; Tan, Y.; Wang, Q. Evaluation of MAIAC aerosol retrievals over China. Atmos. Environ. 2019, 202, 8-16. [CrossRef]

57. Tao, M.; Wang, J.; Li, R.; Wang, L.; Wang, L.; Wang, Z.; Tao, J.; Che, H.; Chen, L. Performance of MODIS high-resolution MAIAC aerosol algorithm in China: Characterization and limitation. Atmos. Environ. 2019, 213, 159-169. [CrossRef]

58. He, L.; Zhong, Z.; Yin, F.; Wang, D. Impact of Energy Consumption on Air Quality in Jiangsu Province of China. Sustainability 2018, 10, 94. [CrossRef]

59. Qiu, Z.; Ali, A.; Nichol, J.; Bilal, M.; Tiwari, P.; Habtemicheal, B.; Almazroui, M.; Mondal, S.; Mazhar, U.; Wang, Y.; et al. Spatiotemporal Investigations of Multi-Sensor Air Pollution Data over Bangladesh during COVID-19 Lockdown. Remote Sens. 2021, 13, 877. [CrossRef]

60. Ichoku, C.; Chu, D.A.; Mattoo, S.; Kaufman, Y.J.; Remer, L.A.; Tanré, D.; Slutsker, I.; Holben, B.N. A spatio-temporal approach for global validation and analysis of MODIS aerosol products. Geophys. Res. Lett. 2002, 29. [CrossRef]

61. Zhang, J.; Reid, J.S. MODIS aerosol product analysis for data assimilation: Assessment of over-ocean level 2 aerosol optical thickness retrievals. J. Geophys. Res. Space Phys. 2006, 111. [CrossRef]

62. Kahn, R.A.; Gaitley, B.J.; Garay, M.J.; Diner, D.J.; Eck, T.F.; Smirnov, A.; Holben, B.N. Multiangle Imaging SpectroRadiometer global aerosol product assessment by comparison with the Aerosol Robotic Network. J. Geophys. Res. Space Phys. 2010, 115. [CrossRef]

63. Bilal, M.; Nazeer, M.; Nichol, J.E.; Bleiweiss, M.P.; Qiu, Z.; Jäkel, E.; Campbell, J.R.; Atique, L.; Huang, X.; Lolli, S. A Simplified and Robust Surface Reflectance Estimation Method (SREM) for Use over Diverse Land Surfaces Using Multi-Sensor Data. Remote Sens. 2019, 11, 1344. [CrossRef]

64. Xie, Y.; Zhang, Y.; Xiong, X.; Qu, J.J.; Che, H. Validation of MODIS aerosol optical depth product over China using CARSNET measurements. Atmos. Environ. 2011, 45, 5970-5978. [CrossRef]

65. Ali, A.; Assiri, M. Analysis of AOD from MODIS-Merged DT-DB Products Over the Arabian Peninsula. Earth Syst. Environ. 2019, 3, 625-636. [CrossRef]

66. Mann, H.B. Nonparametric tests against trend. Econometrica 1945, 13, 245-259. [CrossRef]

67. Kendall, M.G. Rank Correlation Methods, 4th ed.; Charles Griffin: London, UK, 1975; ISBN 0195208374.

68. Sen, P.K. Estimates of the Regression Coefficient Based on Kendall's Tau. J. Am. Stat. Assoc. 1968, 63, 1379-1389. [CrossRef]

69. Li, Z.; Zhao, X.; Kahn, R.; Mishchenko, M.; Remer, L.; Lee, K.H.; Wang, M.; Laszlo, I.; Nakajima, T.; Maring, H. Un-certainties in satellite remote sensing of aerosols and impact on monitoring its long-term trend: A review and perspective. Ann. Geophys. 2009, 27, 2755-2770. [CrossRef]

70. Zhao, H.; Gui, K.; Ma, Y.; Wang, Y.; Wang, Y.; Wang, H.; Zheng, Y.; Li, L.; Zhang, L.; Che, H.; et al. Climatological variations in aerosol optical depth and aerosol type identification in Liaoning of Northeast China based on MODIS data from 2002 to 2019. Sci. Total Environ. 2021, 781, 146810. [CrossRef]

71. Sun, K.; Chen, X. Spatio-temporal distribution of localized aerosol loading in China: A satellite view. Atmos. Environ. 2017, 163, 35-43. [CrossRef]

72. Luo, Y.; Zheng, X.; Zhao, T.; Chen, J. A climatology of aerosol optical depth over China from recent 10 years of MODIS remote sensing data. Int. J. Clim. 2013, 34, 863-870. [CrossRef] 
73. Liu, X.; Chen, Q.; Che, H.; Zhang, R.; Gui, K.; Zhang, H.; Zhao, T. Spatial distribution and temporal variation of aerosol optical depth in the Sichuan basin, China, the recent ten years. Atmos. Environ. 2016, 147, 434-445. [CrossRef]

74. Dickerson, R. The Impact of Aerosols on Solar Ultraviolet Radiation and Photochemical Smog. Science 1997, 278, 827-830. [CrossRef]

75. Li, L.; Wang, Y. What drives the aerosol distribution in Guangdong-The most developed province in Southern China? Sci. Rep. 2015, 4, srep05972. [CrossRef] [PubMed]

76. Bian, Y.X.; Zhao, C.; Ma, N.; Chen, J.; Xu, W. A study of aerosol liquid water content based on hygroscopicity measurements at high relative humidity in the North China Plain. Atmos. Chem. Phys. Discuss. 2014, 14, 6417-6426. [CrossRef]

77. Zhang, L.; Sun, J.Y.; Shen, X.J.; Zhang, Y.M.; Che, H.; Ma, Q.L.; Zhang, X.Y.; Ogren, J.A. Observations of relative humidity effects on aerosol light scattering in the Yangtze River Delta of China. Atmos. Chem. Phys. Discuss. 2015, 15, 8439-8454. [CrossRef]

78. He, Q.; Zhang, M.; Huang, B. Spatio-temporal variation and impact factors analysis of satellite-based aerosol optical depth over China from 2002 to 2015. Atmos. Environ. 2016, 129, 79-90. [CrossRef]

79. Zhang, Z.; Zhang, M.; Bilal, M.; Su, B.; Zhang, C.; Guo, L. Comparison of MODIS- and CALIPSO-Derived Temporal Aerosol Optical Depth over Yellow River Basin (China) from 2007 to 2015. Earth Syst. Environ. 2020, 4, 1-16. [CrossRef]

80. Wang, L.; Gong, W.; Xia, X.; Zhu, J.; Li, J.; Zhu, Z. Long-term observations of aerosol optical properties at Wuhan, an urban site in Central China. Atmos. Environ. 2015, 101, 94-102. [CrossRef]

81. Cheng, T.; Xu, C.; Duan, J.; Wang, Y.; Leng, C.; Tao, J.; Che, H.; He, Q.; Wu, Y.; Zhang, R.; et al. Seasonal variation and difference of aerosol optical properties in columnar and surface atmospheres over Shanghai. Atmos. Environ. 2015, 123, 315-326. [CrossRef]

82. Kang, N.; Kumar, K.R.; Hu, K.; Yu, X.; Yin, Y. Long-term (2002-2014) evolution and trend in Collection 5.1 Level-2 aerosol products derived from the MODIS and MISR sensors over the Chinese Yangtze River Delta. Atmos. Res. 2016, 181, 29-43. [CrossRef]

83. Kang, N.; Kumar, K.R.; Yu, X.; Yin, Y. Column-integrated aerosol optical properties and direct radiative forcing over the urban-industrial megacity Nanjing in the Yangtze River Delta, China. Environ. Sci. Pollut. Res. 2016, 23, 17532-17552. [CrossRef]

84. Hu, K.; Kumar, K.R.; Kang, N.; Boiyo, R.; Wu, J. Spatiotemporal characteristics of aerosols and their trends over mainland China with the recent Collection 6 MODIS and OMI satellite datasets. Environ. Sci. Pollut. Res. 2018, 25, 6909-6927. [CrossRef] [PubMed]

85. More, S.; Kumar, P.P.; Gupta, P.; Devara, P.; Aher, G. Comparison of Aerosol Products Retrieved from AERONET, MICROTOPS and MODIS over a Tropical Urban City, Pune, India. Aerosol. Air Qual. Res. 2013, 13, 107-121. [CrossRef]

86. Zhang, L.; Zhang, M.; Yao, Y. Multi-Time Scale Analysis of Regional Aerosol Optical Depth Changes in National-Level Urban Agglomerations in China Using Modis Collection 6.1 Datasets from 2001 to 2017. Remote Sens. 2019, 11, 201. [CrossRef]

87. Tiwari, S.; Hopke, P.K.; Attri, S.D.; Soni, V.K.; Singh, A.K. Variability in optical properties of atmospheric aerosols and their frequency distribution over a mega city "New Delhi," India. Environ. Sci. Pollut. Res. 2016, 23, 8781-8793. [CrossRef] [PubMed]

88. Filonchyk, M.; Hurynovich, V.; Yan, H. Trends in aerosol optical properties over Eastern Europe based on MODIS-Aqua. Geosci. Front. 2020, 11, 2169-2181. [CrossRef]

89. Lu, Z.; Streets, D.; Zhang, Q.; Wang, S.; Carmichael, G.R.; Cheng, Y.; Wei, C.; Chin, M.; Diehl, T.; Tan, Q. Sulfur dioxide emissions in China and sulfur trends in East Asia since 2000. Atmos. Chem. Phys. Discuss. 2010, 10, 6311-6331. [CrossRef]

90. Zhao, B.; Jiang, J.H.; Gu, Y.; Diner, D.; Worden, J.; Liou, K.-N.; Su, H.; Xing, J.; Garay, M.; Huang, L. Decadal-scale trends in regional aerosol particle properties and their linkage to emission changes. Environ. Res. Lett. 2017, 12, 054021. [CrossRef]

91. Li, J. Pollution Trends in China from 2000 to 2017: A Multi-Sensor View from Space. Remote Sens. 2020, 12, 208. [CrossRef]

92. De Leeuw, G.; Sogacheva, L.; Rodriguez, E.; Kourtidis, K.; Georgoulias, A.; Alexandri, G.; Amiridis, V.; Proestakis, E.; Marinou, E.; Xue, Y.; et al. Two decades of satellite observations of AOD over mainland China using ATSR-2, AATSR and MODIS/Terra: Data set evaluation and large-scale patterns. Atmos. Chem. Phys. Discuss. 2018, 18, 1573-1592. [CrossRef]

93. Sogacheva, L.; De Leeuw, G.; Rodriguez, E.; Kolmonen, P.; Georgoulias, A.; Alexandri, G.; Kourtidis, K.; Proestakis, E.; Marinou, E.; Amiridis, V.; et al. Spatial and seasonal variations of aerosols over China from two decades of multi-satellite observations-Part 1: ATSR (1995-2011) and MODIS C6.1 (2000-2017). Atmos. Chem. Phys. Discuss. 2018, 18, 11389-11407. [CrossRef]

94. Ma, Z.; Hu, X.; Sayer, A.; Levy, R.; Zhang, Q.; Xue, Y.; Tong, S.; Bi, J.; Huang, L.; Liu, Y. Satellite-Based Spatiotemporal Trends in PM 2.5 Concentrations: China, 2004-2013. Environ. Heal. Perspect. 2016, 124, 184-192. [CrossRef] [PubMed]

95. Mehta, M.; Singh, R.; Singh, A.; Singh, N. Anshumali Recent global aerosol optical depth variations and trends-A comparative study using MODIS and MISR level 3 datasets. Remote Sens. Environ. 2016, 181, 137-150. [CrossRef]

96. Chen, L.-X.; Zhang, B.; Zhu, W.-Q.; Zhou, X.-J.; Luo, Y.-F.; He, J.-H. Variation of atmospheric aerosol optical depth and its relationship with climate change in China east of $100^{\circ} \mathrm{E}$ over the last 50 years. Theor. Appl. Clim. 2009, 96, 191-199. [CrossRef]

97. Zhuang, B.; Wang, T.; Li, S.; Liu, J.; Talbot, R.; Mao, H.; Yang, X.; Fu, C.; Yin, C.; Zhu, J.; et al. Optical properties and radiative forcing of urban aerosols in Nanjing, China. Atmos. Environ. 2014, 83, 43-52. [CrossRef]

98. Li, S.; Wang, T.; Xie, M.; Han, Y.; Zhuang, B. Observed aerosol optical depth and angstrom exponent in urban area of Nanjing, China. Atmos. Environ. 2015, 123, 350-356. [CrossRef]

99. Ma, F.; Guan, Z. Seasonal Variations of Aerosol Optical Depth over East China and India in Relationship to the Asian Monsoon Circulation. J. Meteorol. Res. 2018, 32, 648-660. [CrossRef]

100. $\mathrm{Mu}, \mathrm{Q} . ;$ Atmos. Chem. Phys. Discuss. 2014, 14, 9597-9612. [CrossRef]

101. Zhu, J.; Che, H.; Xia, X.; Chen, H.; Goloub, P.; Zhang, W. Column-integrated aerosol optical and physical properties at a regional background atmosphere in North China Plain. Atmos. Environ. 2014, 84, 54-64. [CrossRef] 
102. Shen, X.; Sun, J.; Zhang, X.; Zhang, Y.; Zhang, L.; Che, H.; Ma, Q.; Yu, X.; Yue, Y. Characterization of submicron aerosols and effect on visibility during a severe haze-fog episode in Yangtze River Delta, China. Atmos. Environ. 2015, 120, 307-316. [CrossRef]

103. Che, H.; Qi, B.; Zhao, H.; Xia, X.; Eck, T.F.; Goloub, P.; Dubovik, O.; Estelles, V.; Cuevas-Agulló, E.; Blarel, L.; et al. Aerosol optical properties and direct radiative forcing based on measurements from the China Aerosol Remote Sensing Network (CARSNET) in eastern China. Atmos. Chem. Phys. Discuss. 2018, 18, 405-425. [CrossRef]

104. Mao, Y.-H.; Liao, H.; Chen, H.-S. Impacts of East Asian summer and winter monsoons on interannual variations of mass concentrations and direct radiative forcing of black carbon over eastern China. Atmos. Chem. Phys. Discuss. 2017, 17, 4799-4816. [CrossRef]

105. Walters, R. Toxic Atmospheres Air Pollution, Trade and the Politics of Regulation. Crit. Criminol. 2010, 18, 307-323. [CrossRef]

106. Wang, Y.; Wu, Z.; Ma, N.; Wu, Y.; Zeng, L.; Zhao, C.; Wiedensohler, A. Statistical analysis and parameterization of the hygroscopic growth of the sub-micrometer urban background aerosol in Beijing. Atmos. Environ. 2018, 175, 184-191. [CrossRef]

107. Filonchyk, M.; Yan, H.; Zhang, Z.; Yang, S.; Li, W.; Li, Y. Combined use of satellite and surface observations to study aerosol optical depth in different regions of China. Sci. Rep. 2019, 9, 6174. [CrossRef] [PubMed]

108. Sun, E.; Che, H.; Xu, X.; Wang, Z.; Lu, C.; Gui, K.; Zhao, H.; Zheng, Y.; Wang, Y.; Wang, H.; et al. Variation in MERRA-2 aerosol optical depth over the Yangtze River Delta from 1980 to 2016. Theor. Appl. Clim. 2018, 136, 363-375. [CrossRef]

109. Xia, X.; Chen, H.; Goloub, P.; Zong, X.; Zhang, W.; Wang, P. Climatological aspects of aerosol optical properties in North China Plain based on ground and satellite remote-sensing data. J. Quant. Spectrosc. Radiat. Transf. 2013, 127, 12-23. [CrossRef]

110. Zhao, T.X.-P.; Stowe, L.L.; Smirnov, A.; Crosby, D.; Sapper, J.; McClain, C.R. Development of a Global Validation Package for Satellite Oceanic Aerosol Optical Thickness Retrieval Based on AERONET Observations and Its Application to NOAA/NESDIS Operational Aerosol Retrievals. J. Atmos. Sci. 2002, 59, 294-312. [CrossRef]

111. Zhang, Z.; Wu, W.; Wei, J.; Song, Y.; Yan, X.; Zhu, L.; Wang, Q. Aerosol optical depth retrieval from visibility in China during 1973-2014. Atmos. Environ. 2017, 171, 38-48. [CrossRef] 